\title{
Melt-polymerization of acrylamide initiated by nucleophiles: a route towards highly branched and amorphous polyamide 3
}

\section{Supporting Information}

David Edinger, ${ }^{a, b}$ Hansjoerg Weber, ${ }^{c}$ Ema Žagar, ${ }^{d}$ David Pahovnik, ${ }^{d}$ Christian Slugovc ${ }^{a, b, *}$

a Institute for Chemistry and Technology of Materials, Graz University of Technology,

Stremayrgasse 9, 8010 Graz, Austria

${ }^{\mathrm{b}}$ Christian Doppler Laboratory for Organocatalysis in Polymerization, Stremayrgasse 9, 8010

Graz, Austria

${ }^{c}$ Institute of Organic Chemistry, Graz University of Technology, Stremayrgasse 9, 8010 Graz, Austria

${ }^{d}$ National Institute of Chemistry, Department of Polymer Chemistry and Technology, Hajdrihova 19, 1000 Ljubljana, Slovenia

* correspondence to C. Slugovc: slugove@tugraz.at 
Supporting Information

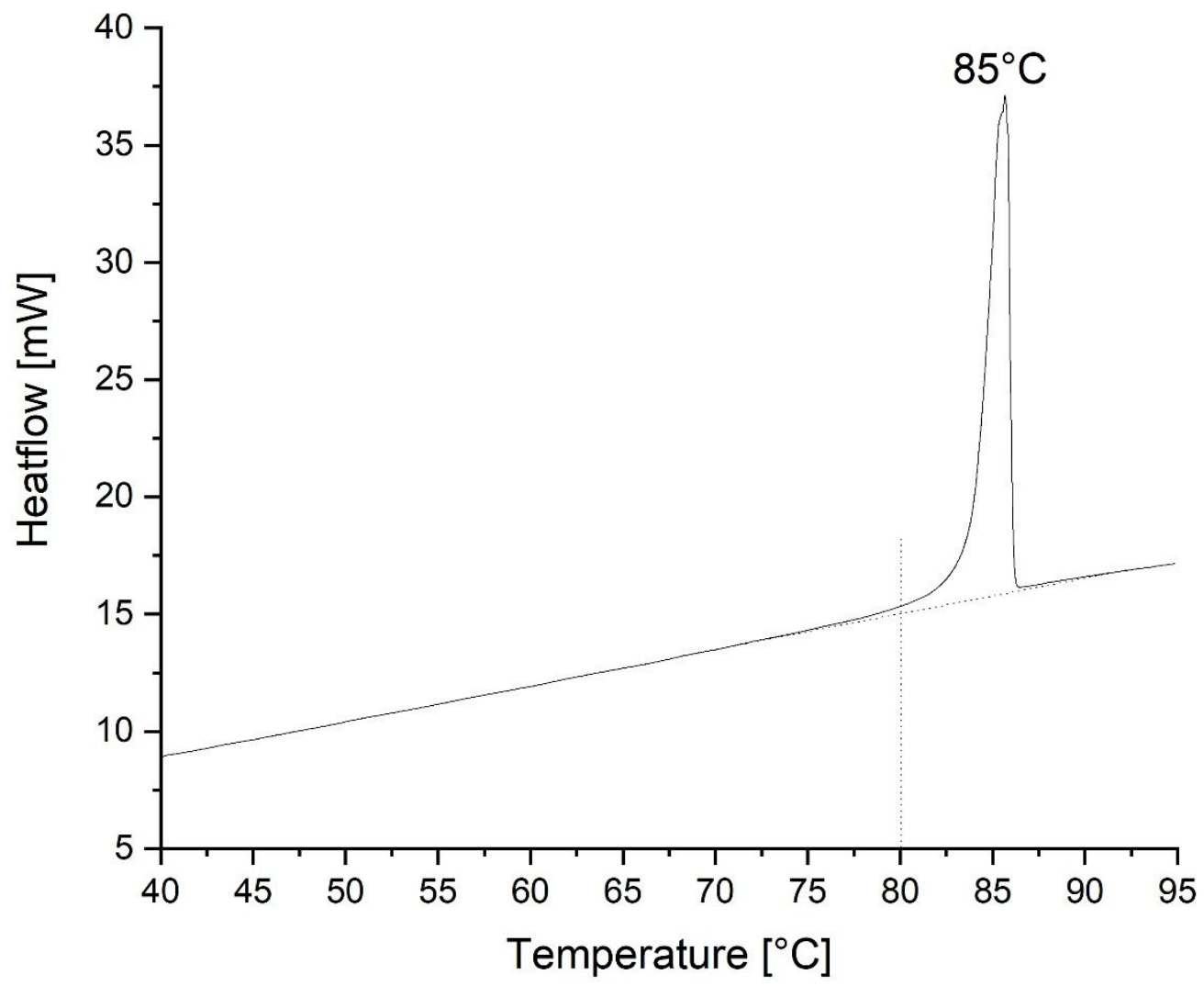

Figure S1. DSC run for determining the melting point of acrylamide (heating rate $5^{\circ} \mathrm{C} / \mathrm{min}$ ). 
Supporting Information
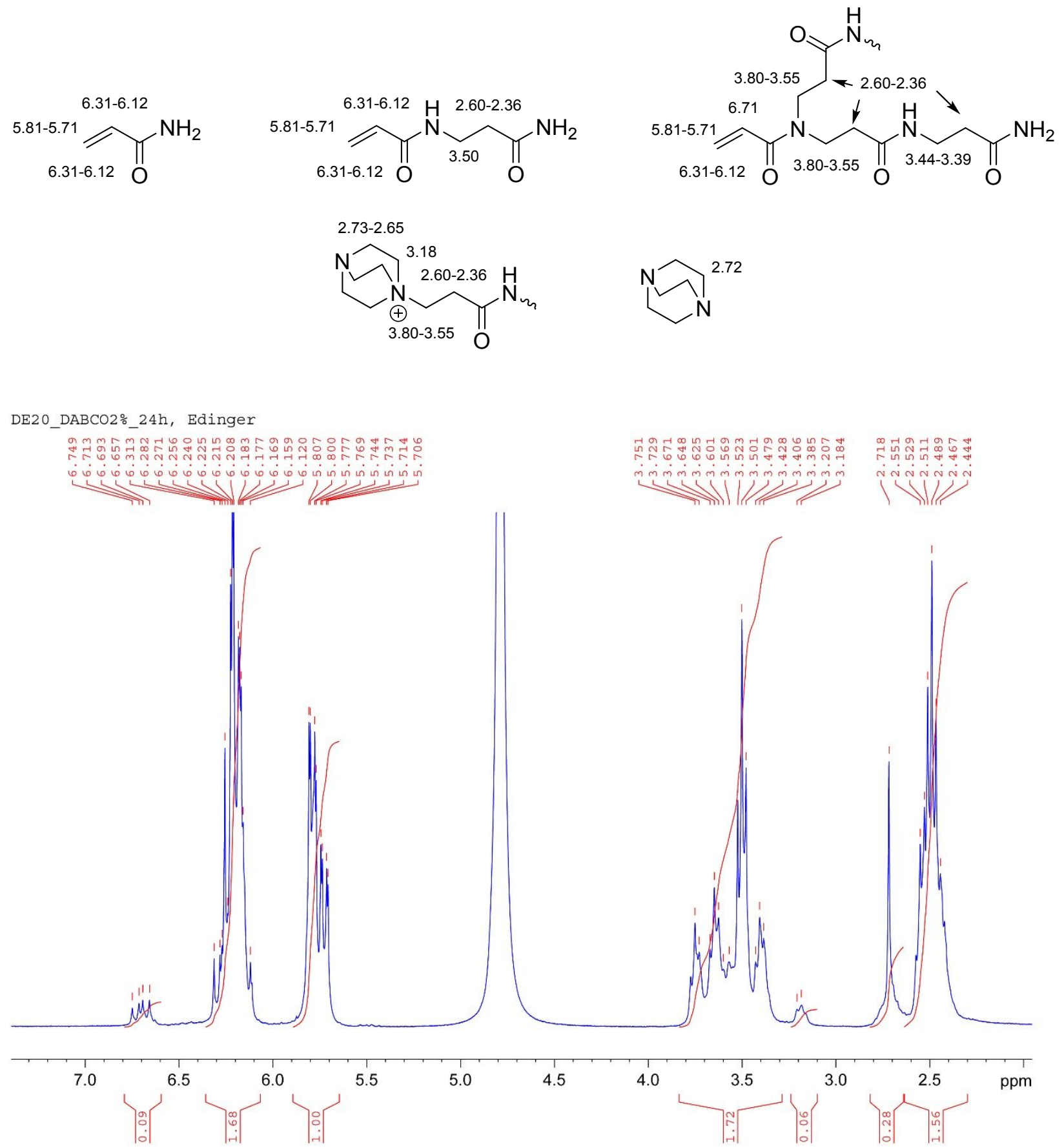

Figure S2. ${ }^{1} \mathrm{H}-\mathrm{NMR}\left(300 \mathrm{MHz}, \mathrm{D}_{2} \mathrm{O}, 25^{\circ} \mathrm{C}\right)$ of the reaction of acrylamide with $\mathrm{DABCO}(2 \mathrm{~mol} \%)$ at $83{ }^{\circ} \mathrm{C}$ after $24 \mathrm{~h}$ (Table, Entry 1$)$. 
Supporting Information
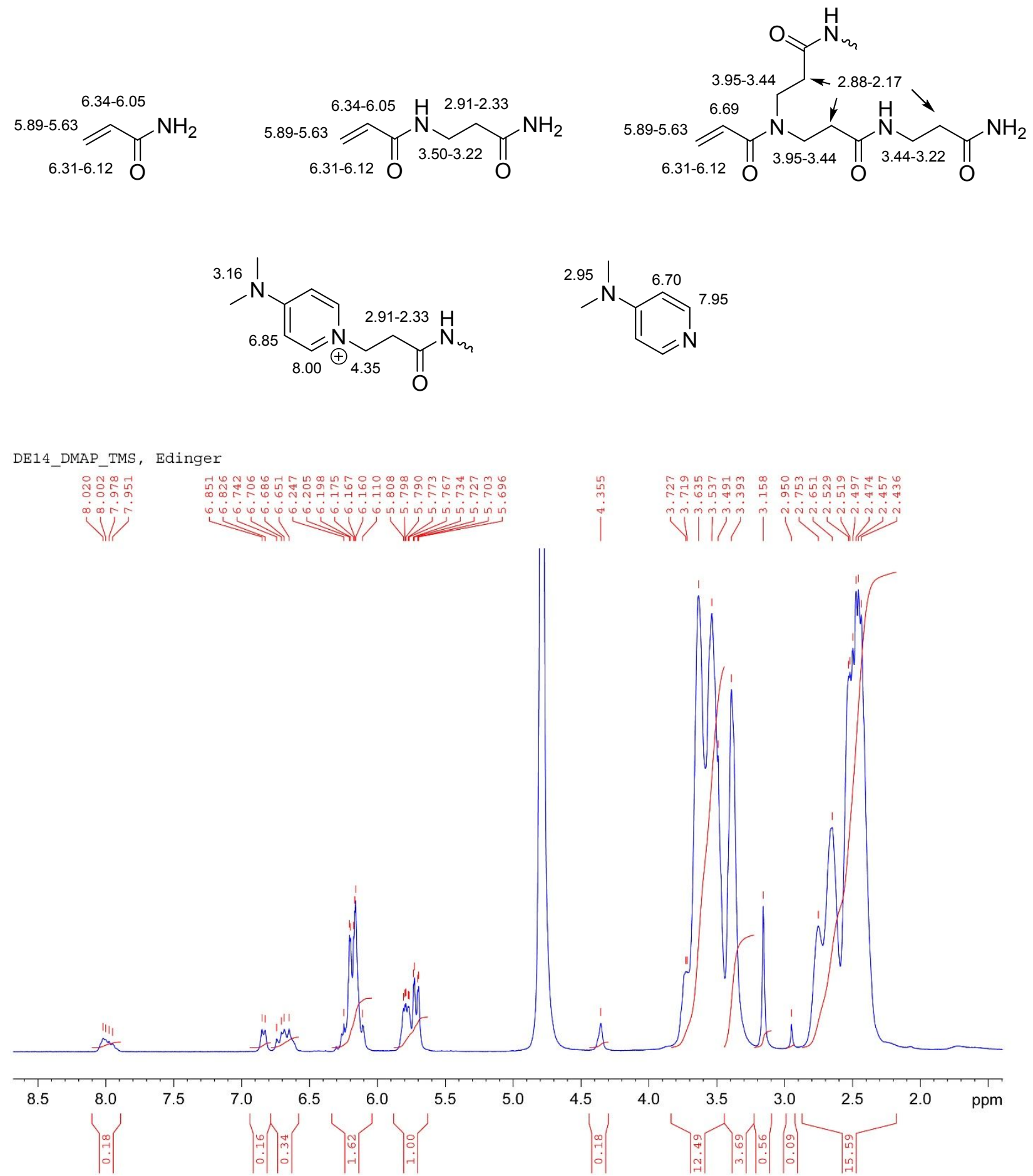

Figure S3. ${ }^{1} \mathrm{H}-\mathrm{NMR}\left(300 \mathrm{MHz}, \mathrm{D}_{2} \mathrm{O}, 25^{\circ} \mathrm{C}\right)$ of the reaction of acrylamide with DMAP (2 mol\%) at $83{ }^{\circ} \mathrm{C}$ after $24 \mathrm{~h}$ (Table 1, Entry 3). 
Supporting Information

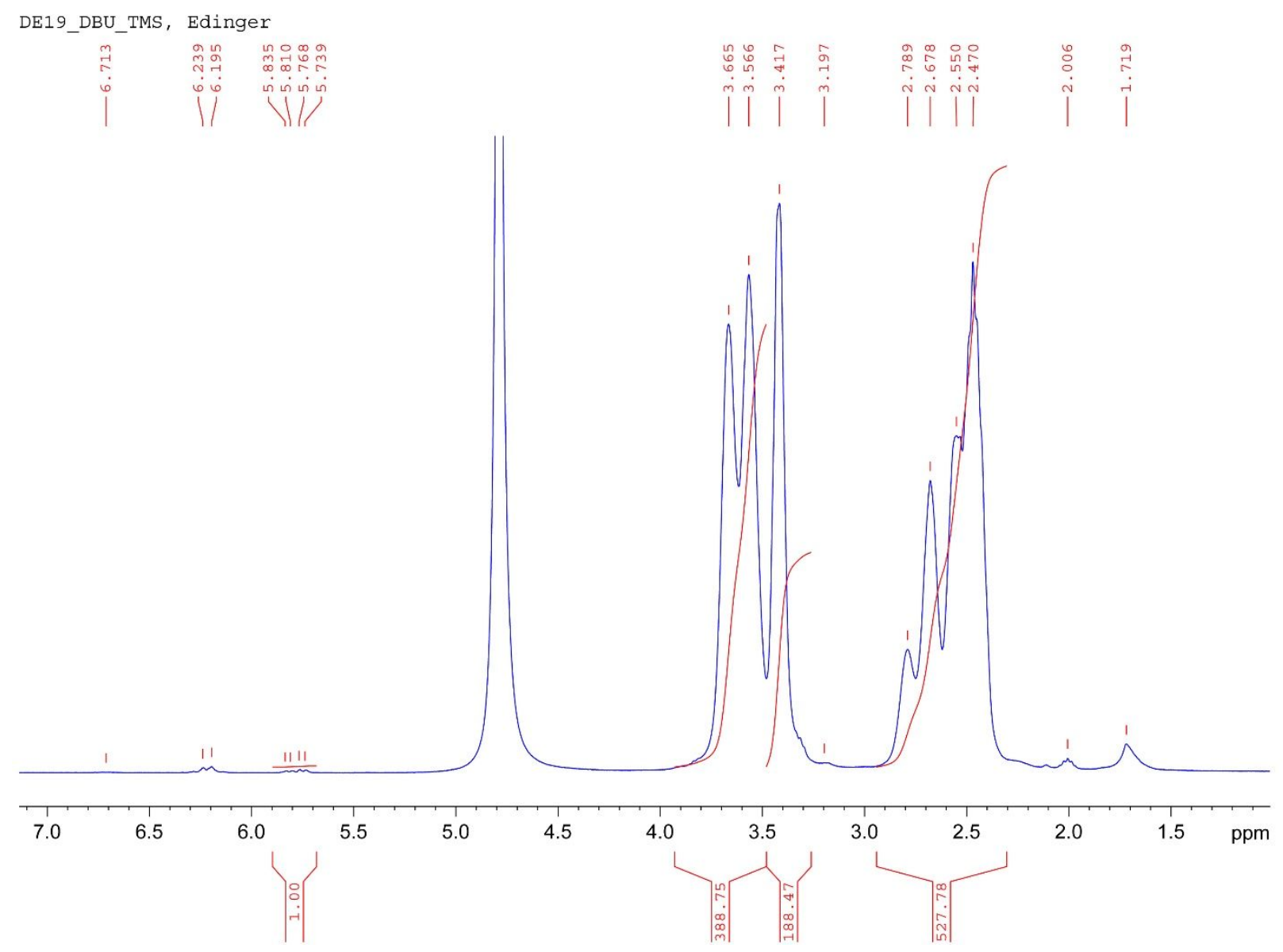

Figure S4. ${ }^{1} \mathrm{H}-\mathrm{NMR}\left(300 \mathrm{MHz}, \mathrm{D}_{2} \mathrm{O}, 25^{\circ} \mathrm{C}\right)$ of the reaction of acrylamide with $\mathrm{DBU}(2 \mathrm{~mol} \%)$ at $83{ }^{\circ} \mathrm{C}$ after $24 \mathrm{~h}$ (Table 1, Entry 4). The signals at 3.20, 2.01 and $1.72 \mathrm{ppm}$ are caused by DBU. 
Supporting Information

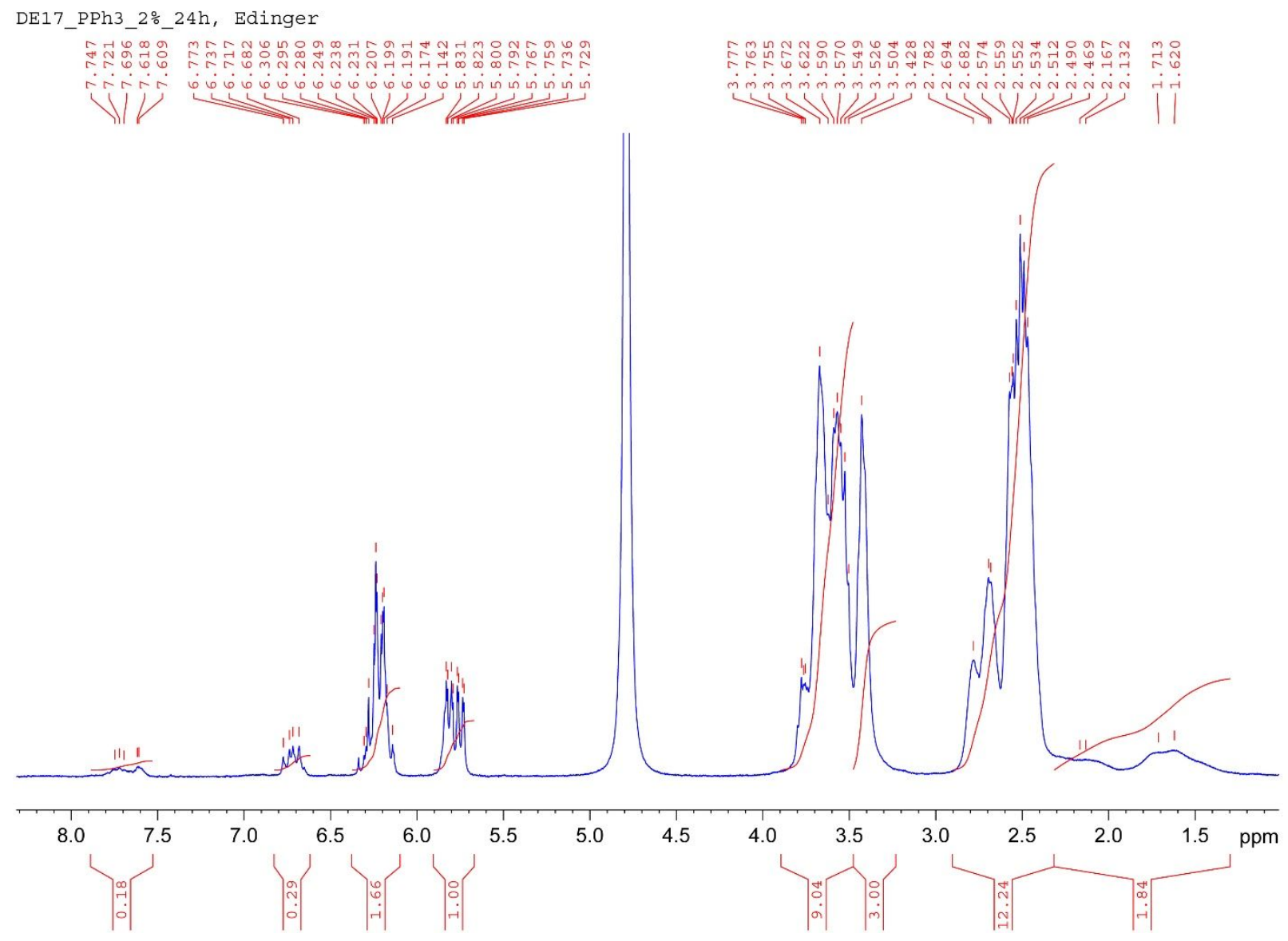

Figure S5. ${ }^{1} \mathrm{H}-\mathrm{NMR}\left(300 \mathrm{MHz}, \mathrm{D}_{2} \mathrm{O}, 25^{\circ} \mathrm{C}\right)$ of the reaction of acrylamide with $\mathrm{PPh}_{3}(2 \mathrm{~mol} \%)$ at $83{ }^{\circ} \mathrm{C}$ after $24 \mathrm{~h}$ (Table 1, Entry 5). The signals at 7.75-7.60 ppm are likely caused by a $\mathrm{PPh}_{3}{ }^{+}$ bearing species; broad peaks below $2.4 \mathrm{ppm}$ indicate the presence of vinyl polymerized acrylamide. 
Supporting Information

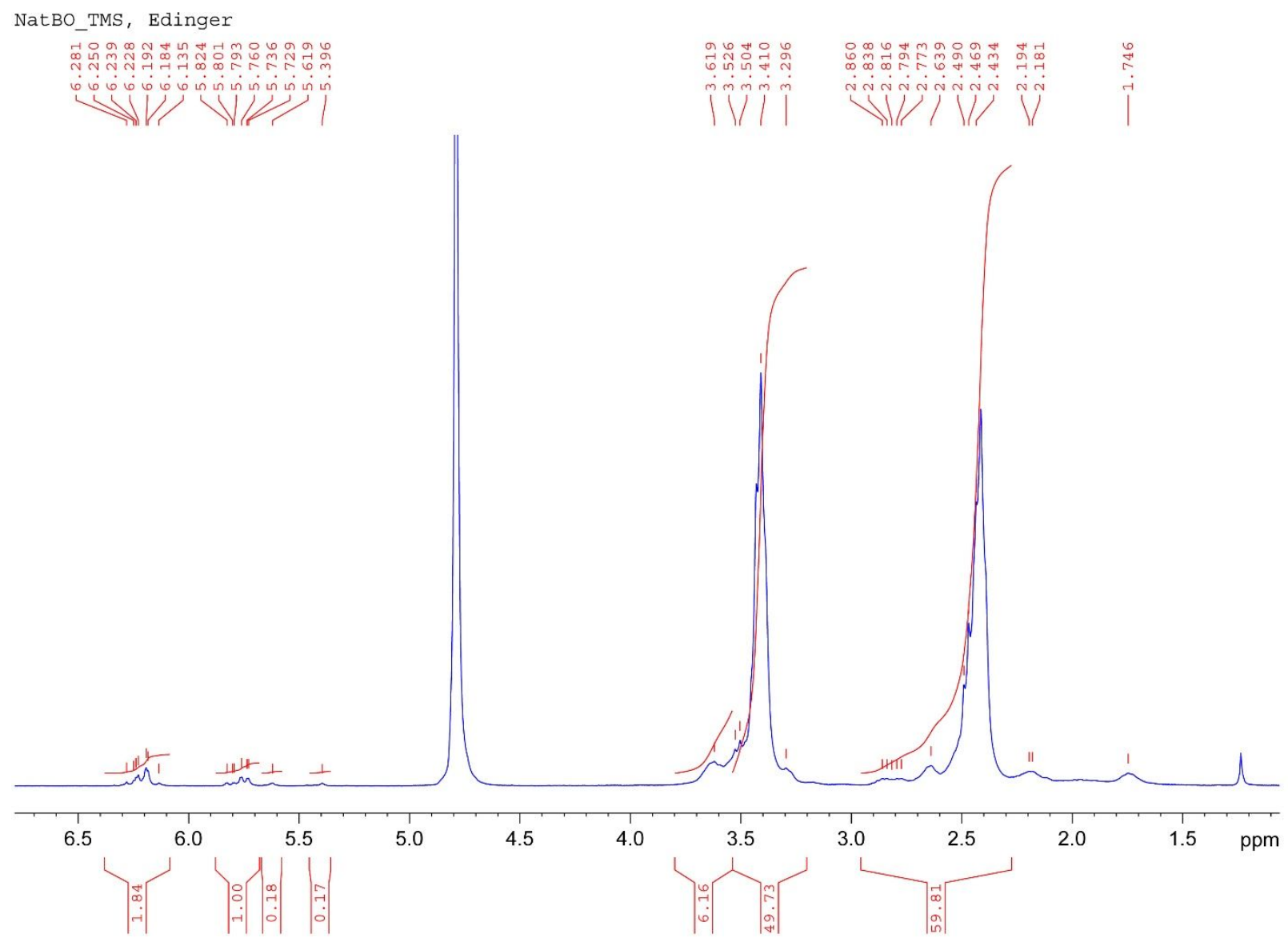

Figure S6. ${ }^{1} \mathrm{H}-\mathrm{NMR}\left(300 \mathrm{MHz}, \mathrm{D}_{2} \mathrm{O}, 25^{\circ} \mathrm{C}\right)$ of the reaction of acrylamide with $\mathrm{NaO}^{\mathrm{t}} \mathrm{Bu}(2 \mathrm{~mol} \%)$ at $83{ }^{\circ} \mathrm{C}$ after $24 \mathrm{~h}$ (Table 1, Entry 6). The signals at 5.62 and $5.40 \mathrm{ppm}$ might indicate a RauhutCurrier type repeat unit. Broad peaks below $2.4 \mathrm{ppm}$ indicate the presence of vinyl polymerized acrylamide. 
Supporting Information

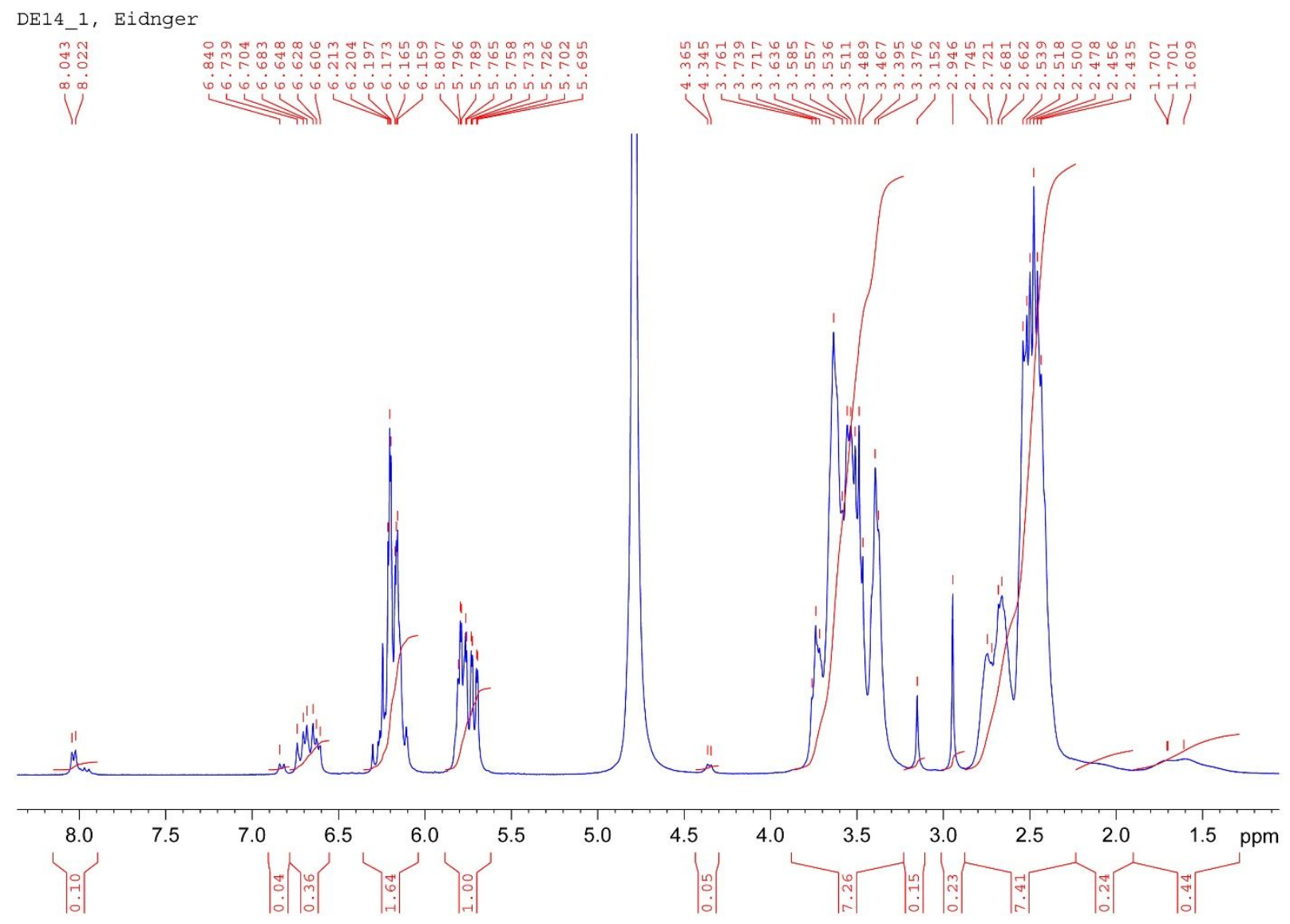

Figure S7. ${ }^{1} \mathrm{H}-\mathrm{NMR}\left(300 \mathrm{MHz}, \mathrm{D}_{2} \mathrm{O}, 25^{\circ} \mathrm{C}\right)$ of the reaction of acrylamide with DMAP (1 mol\%) at $83{ }^{\circ} \mathrm{C}$ after $24 \mathrm{~h}$ (Table 1, Entry 7). Broad peaks below $2.4 \mathrm{ppm}$ indicate the presence of vinyl polymerized acrylamide. 
Supporting Information

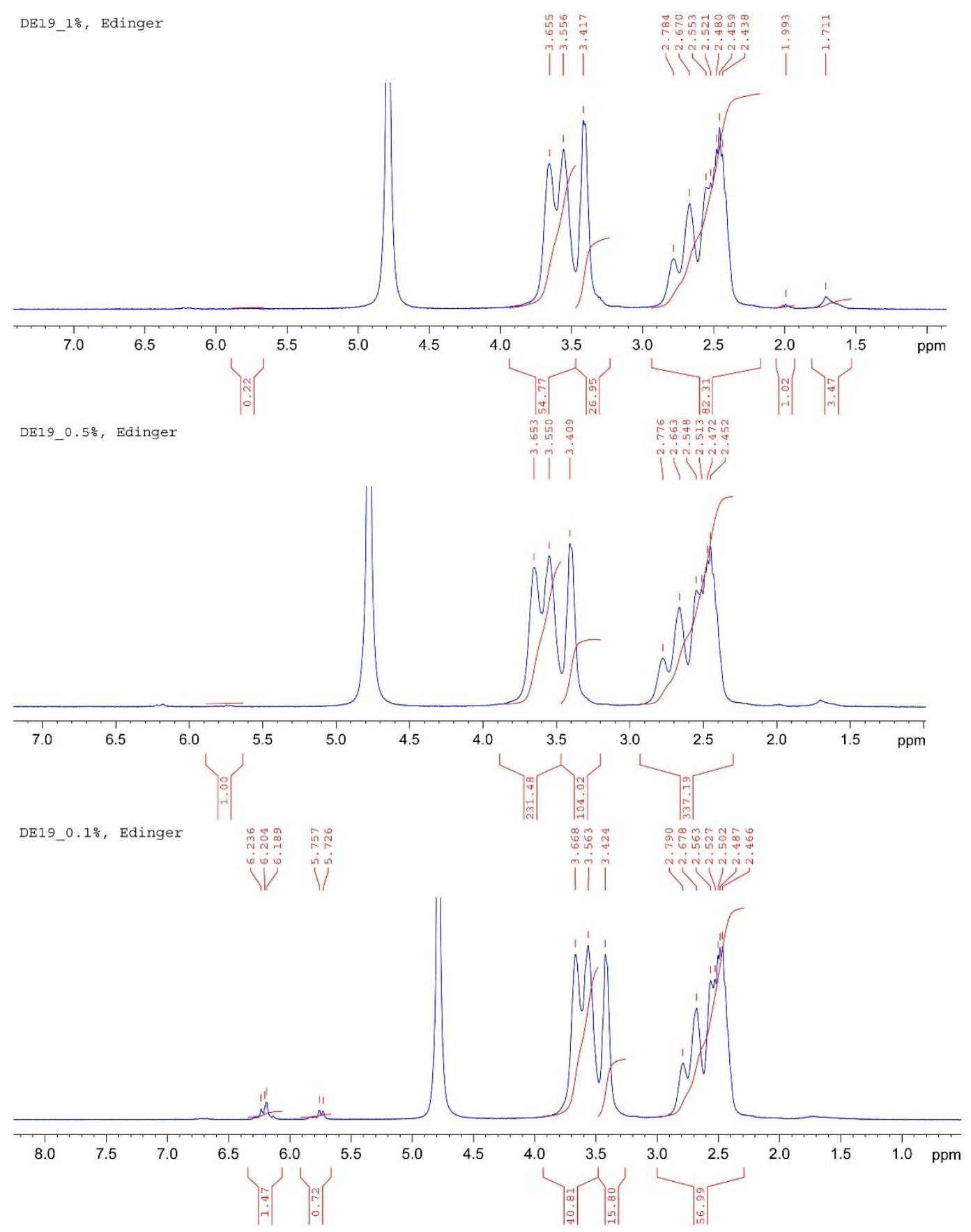

Figure S8. ${ }^{1} \mathrm{H}-\mathrm{NMR}\left(300 \mathrm{MHz}, \mathrm{D}_{2} \mathrm{O}, 25^{\circ} \mathrm{C}\right)$ of the reaction of acrylamide with $\mathrm{DBU}(1,0.5$ and $0.1 \mathrm{~mol} \%$ ) at $83{ }^{\circ} \mathrm{C}$ after $24 \mathrm{~h}$ (Table 1, Entries 8-10). 
Supporting Information
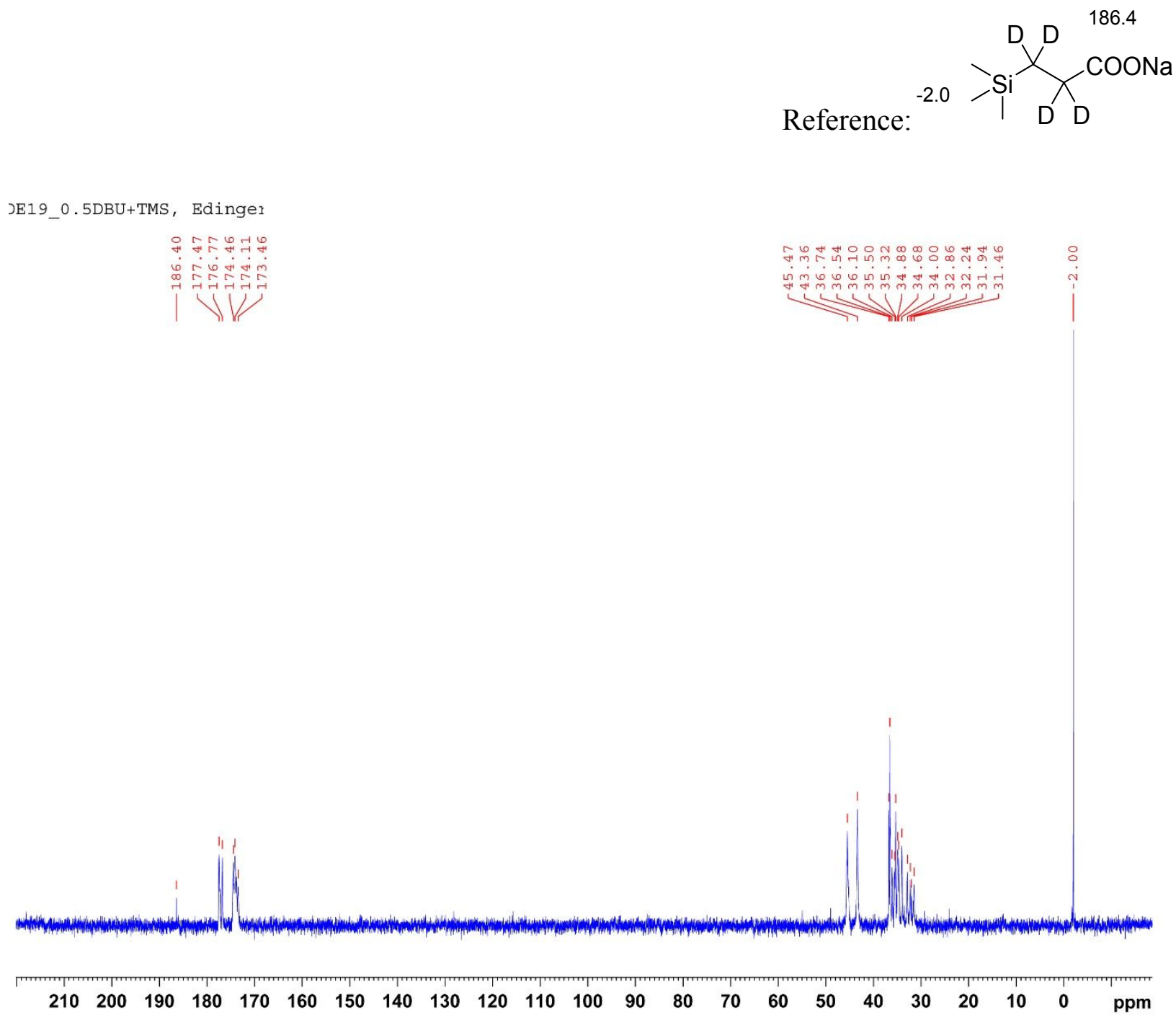

Figure S9. ${ }^{13} \mathrm{C}-\left\{{ }^{1} \mathrm{H}\right\}-\mathrm{NMR}\left(75.5 \mathrm{MHz}, \mathrm{D}_{2} \mathrm{O}, 25^{\circ} \mathrm{C}\right)$ of the reaction of acrylamide with DBU $(0.5$ mol\%) at $83{ }^{\circ} \mathrm{C}$ after $24 \mathrm{~h}$ (cTable 1, Entry 9). Referenced to 2,2,3,3-D -3 -(trimethylsilyl)propionic acid, sodium salt setting the carbon for the trimetylsilyl-group to $-2.0 \mathrm{ppm}$. 
Supporting Information

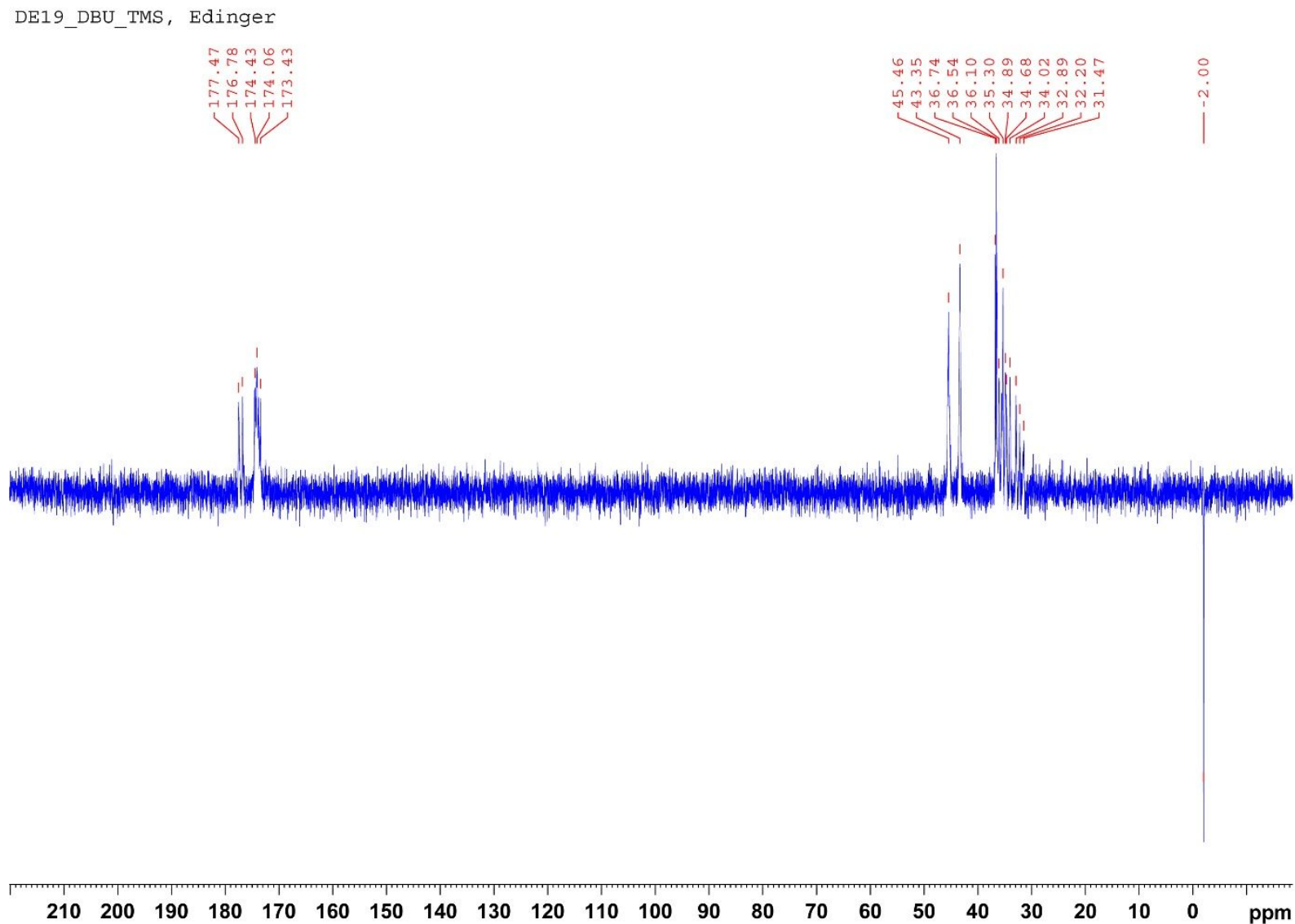

Figure S10. ${ }^{13} \mathrm{C}-J M O D-N M R ~\left(75.5 \mathrm{MHz}, \mathrm{D}_{2} \mathrm{O}, 25^{\circ} \mathrm{C}\right)$ of the reaction of acrylamide with DBU $(0.5 \mathrm{~mol} \%)$ at $83{ }^{\circ} \mathrm{C}$ after $24 \mathrm{~h}$ (Table 1, Entry 9). Referenced to 2,2,3,3- $\mathrm{D}_{4}-3-$ (trimethylsilyl)propionic acid, sodium salt setting the carbon for the trimetylsilyl-group to -2.0 ppm. 
Supporting Information

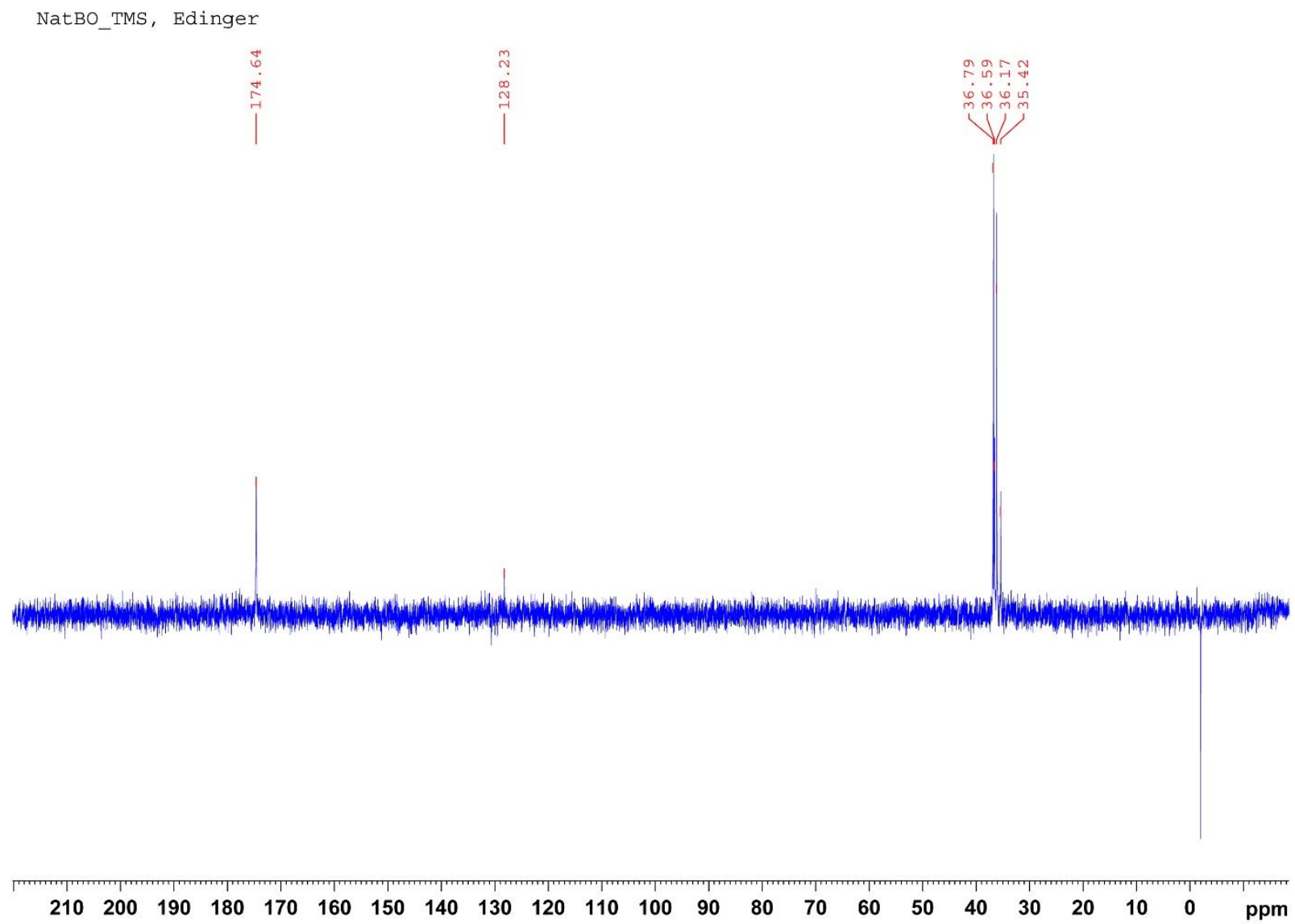

Figure S11. ${ }^{13} \mathrm{C}-\mathrm{JMOD}-\mathrm{NMR}\left(75.5 \mathrm{MHz}, \mathrm{D}_{2} \mathrm{O}, 25^{\circ} \mathrm{C}\right)$ of the reaction of acrylamide with $\mathrm{NaOtBu}$

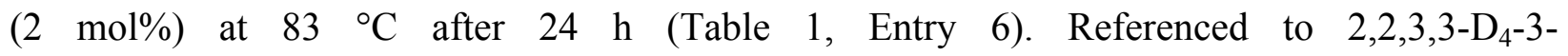
(trimethylsilyl)propionic acid, sodium salt setting the carbon for the trimetylsilyl-group to -2.0 ppm. 
Supporting Information
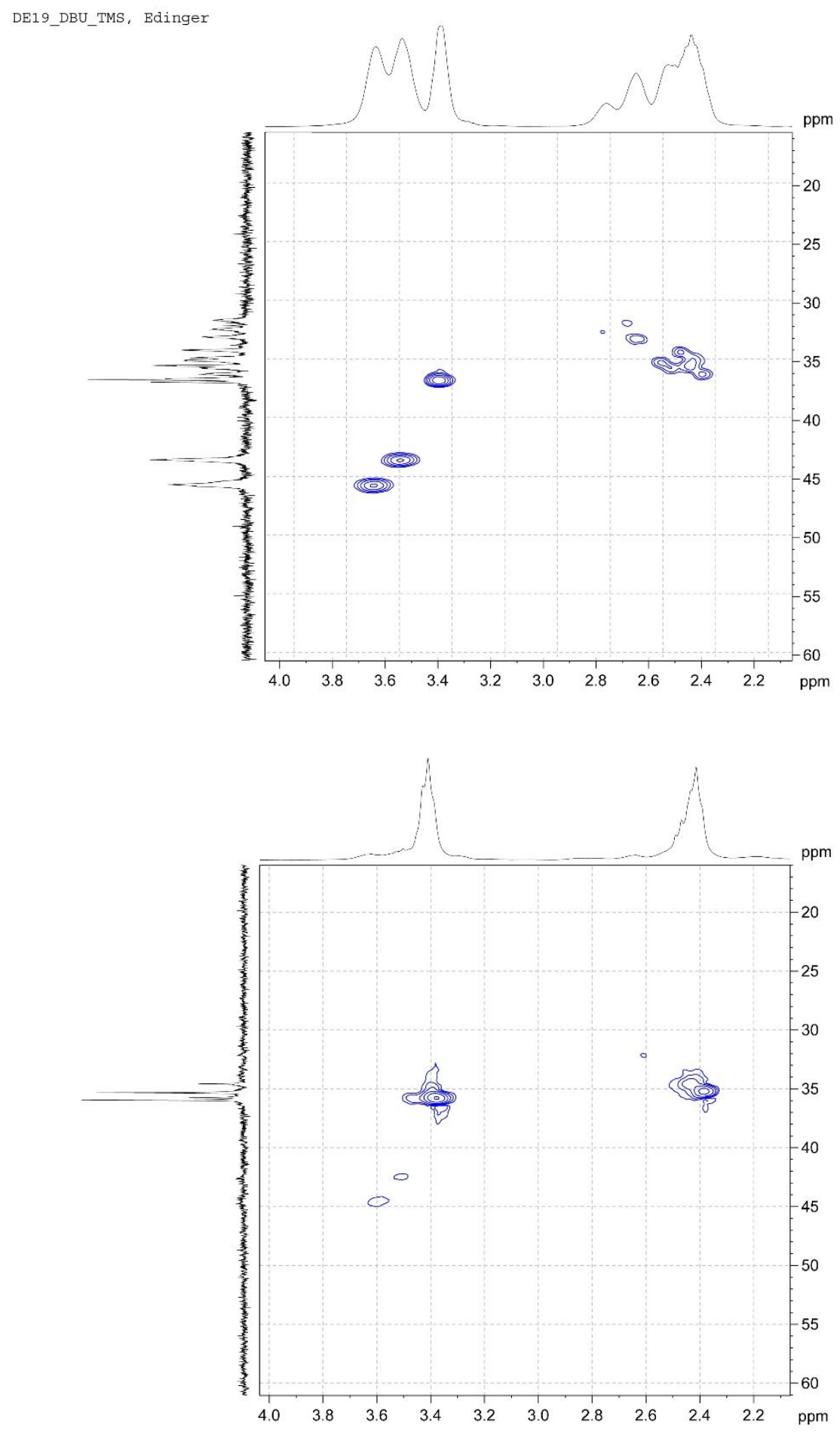

Figure S12. HSQC spectra $\left(\mathrm{D}_{2} \mathrm{O}, 25^{\circ} \mathrm{C}\right)$ of the reaction of acrylamide with $\mathrm{DBU}(0.5 \mathrm{~mol} \%)$ at 83 ${ }^{\circ} \mathrm{C}$ after $24 \mathrm{~h}$ (above) and of the reaction of acrylamide with $\mathrm{NaOtBu}(2 \mathrm{~mol} \%)$ at $83{ }^{\circ} \mathrm{C}$ after $24 \mathrm{~h}$ (below) 
Supporting Information

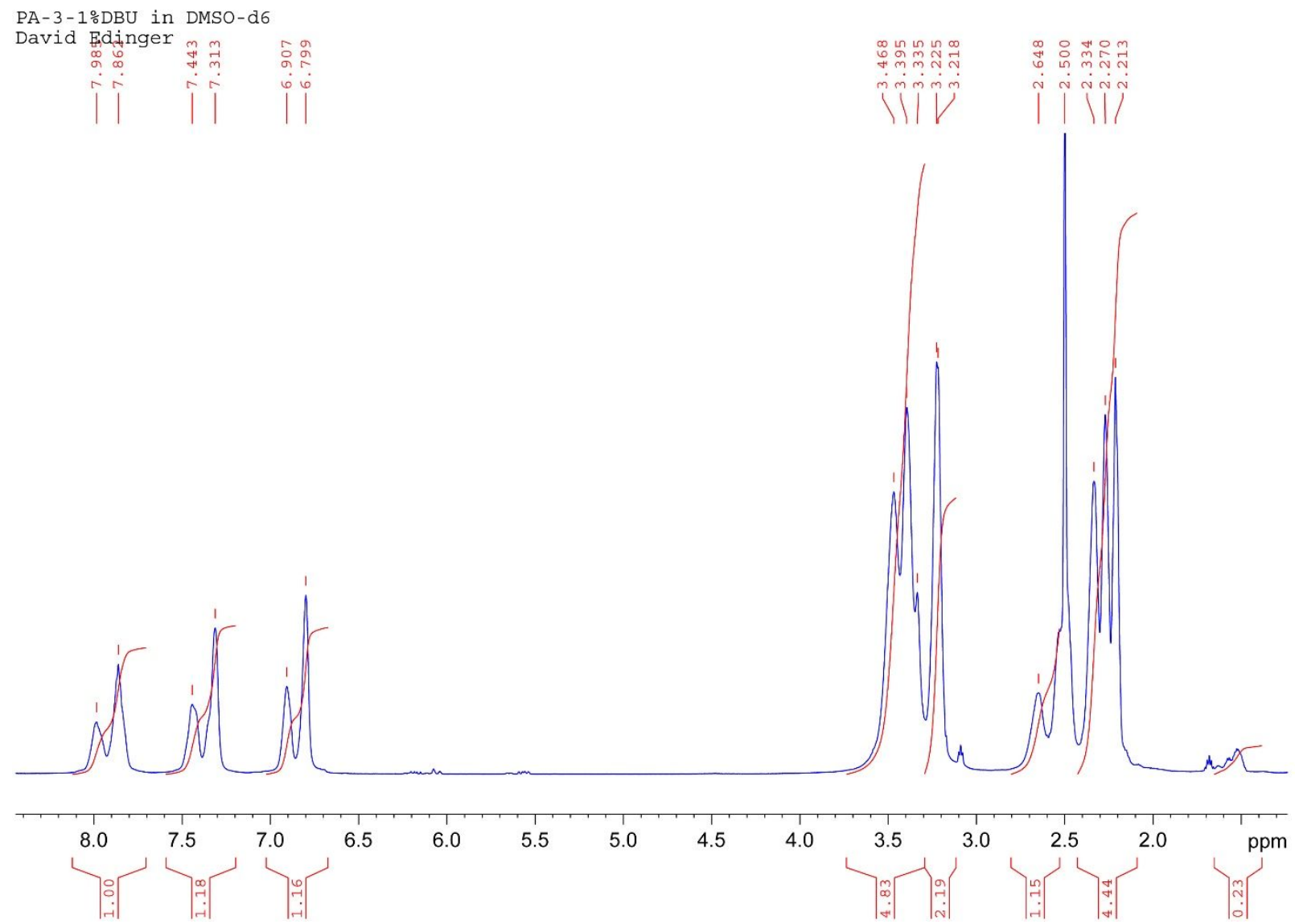

Figure S13. ${ }^{1} \mathrm{H}-\mathrm{NMR}\left(500 \mathrm{MHz}, \mathrm{DMSO}-\mathrm{d}_{6}, 25^{\circ} \mathrm{C}\right)$ of the reaction of acrylamide with DBU $(1$ mol\%) at $83{ }^{\circ} \mathrm{C}$ after $24 \mathrm{~h}$ (Table 1, Entry 8 ). 
Supporting Information

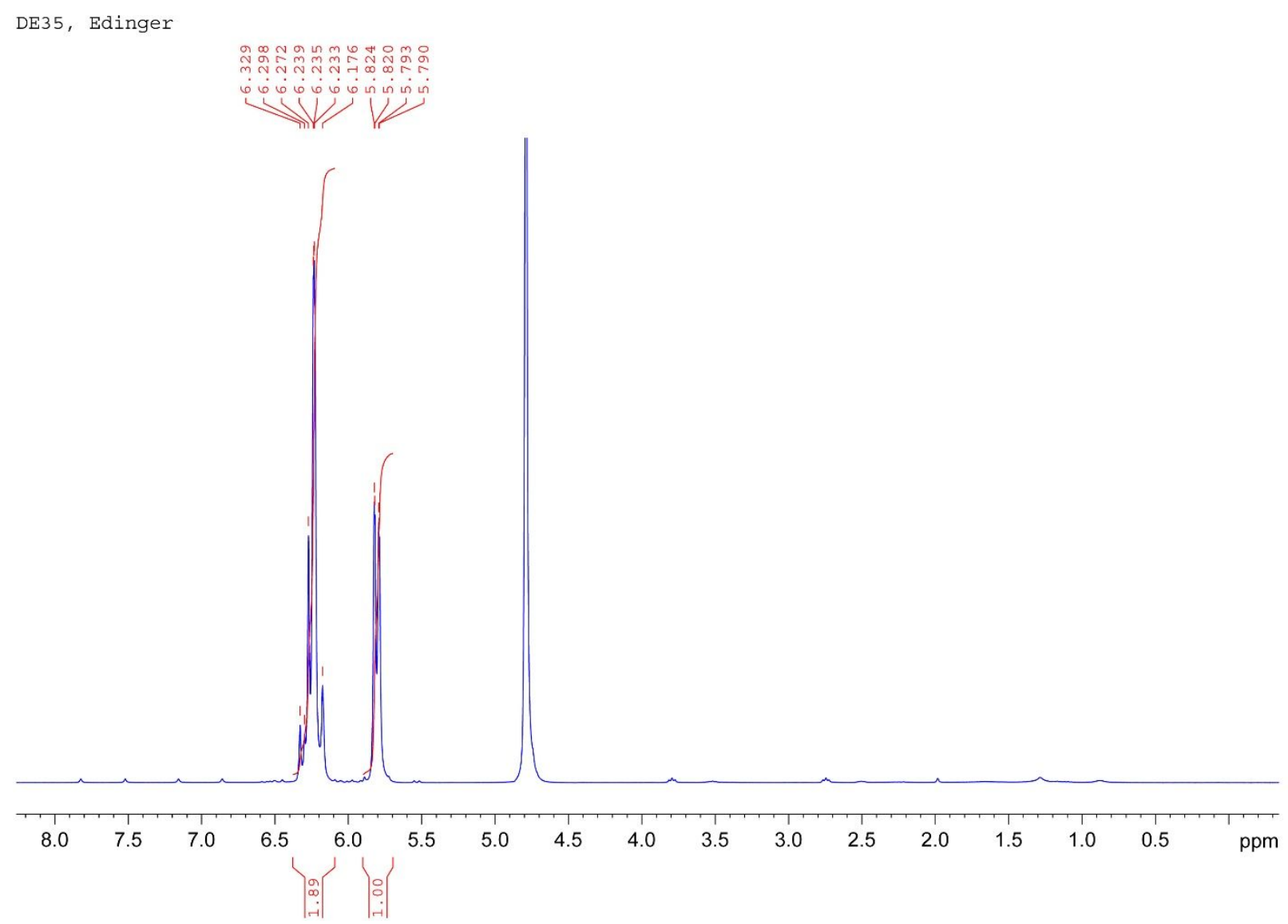

Figure S14. ${ }^{1} \mathrm{H}-\mathrm{NMR}\left(300 \mathrm{MHz}, \mathrm{D}_{2} \mathrm{O}, 25^{\circ} \mathrm{C}\right)$ of ${ }^{15} \mathrm{~N}$-acrylamide. 
Supporting Information

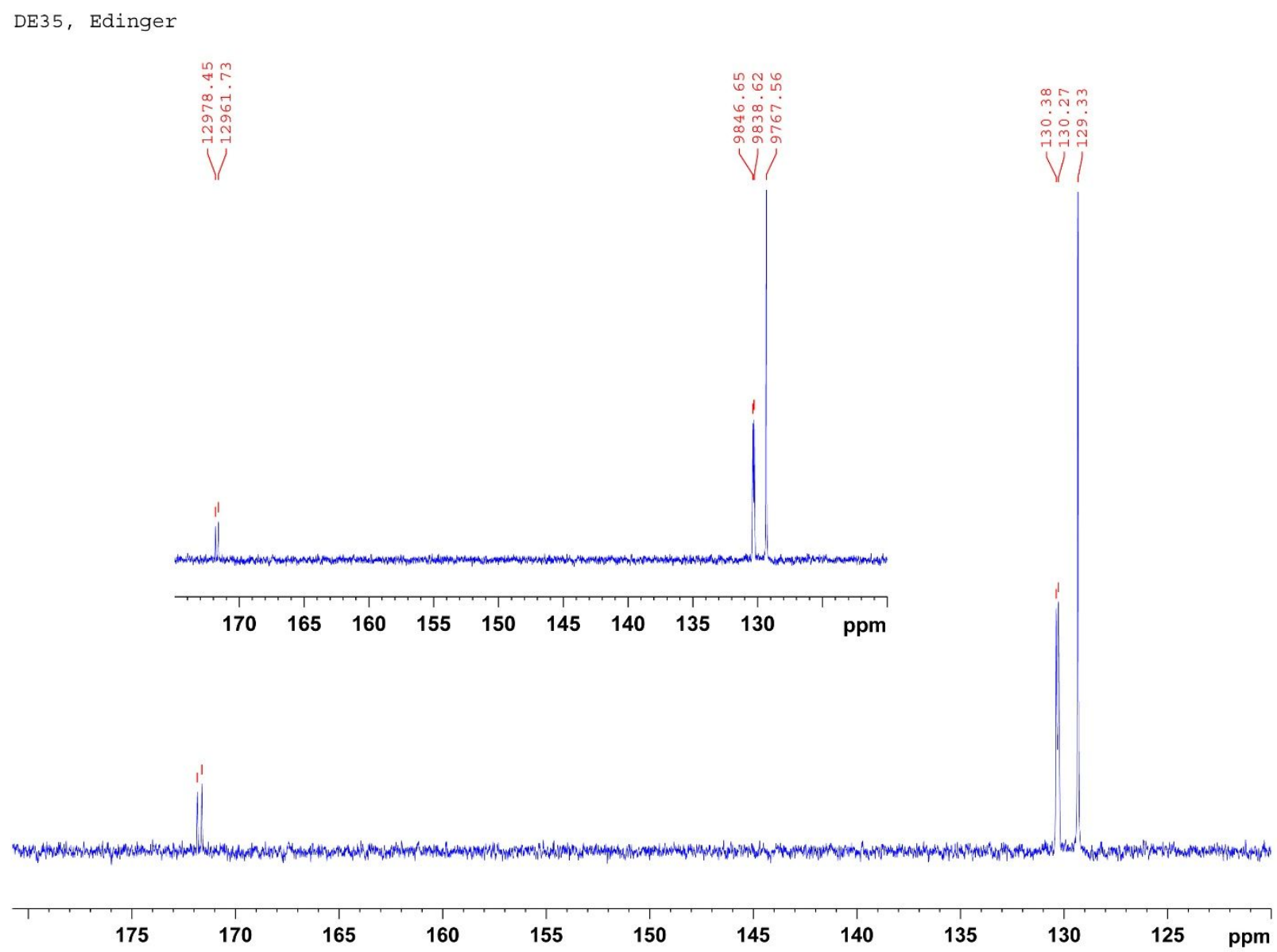

Figure S15. ${ }^{13} \mathrm{C}-\left\{{ }^{1} \mathrm{H}\right\}$-NMR $\left(75.5 \mathrm{MHz}, \mathrm{D}_{2} \mathrm{O}, 25^{\circ} \mathrm{C}\right)$ of ${ }^{15} \mathrm{~N}$-acrylamide.

Coupling constants: ${ }^{1} J\left(\mathrm{C},{ }^{15} \mathrm{~N}\right)=16.7 \mathrm{~Hz},{ }^{2} J\left(\mathrm{C},{ }^{15} \mathrm{~N}\right)=8.0 \mathrm{~Hz}$. 


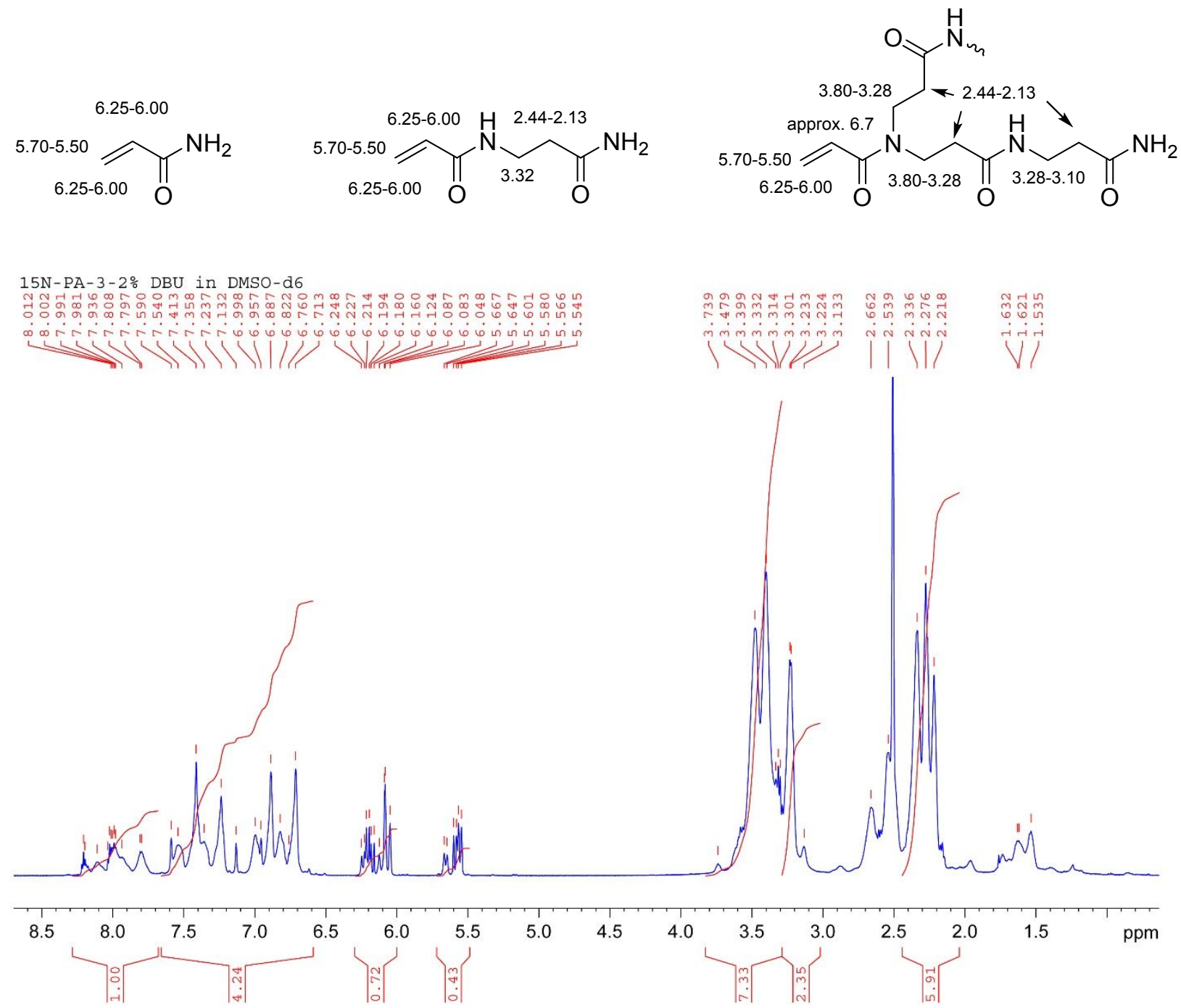

Figure S16. ${ }^{1} \mathrm{H}-\mathrm{NMR}\left(500 \mathrm{MHz}, \mathrm{DMSO}-\mathrm{d}_{6}, 25^{\circ} \mathrm{C}\right)$ of the reaction of acrylamide- ${ }^{15} \mathrm{~N}$ with DBU $(2 \mathrm{~mol} \%)$ at $83^{\circ} \mathrm{C}$ after $24 \mathrm{~h}$ (Table 1 , Entry 8$)$.

From integration of the proton spectrum:

Double bond conversion: $92 \%$; branching $\mathrm{m} / \mathrm{n}=61 \%$; $\mathrm{NH}: \mathrm{NH}_{2}=1: 2.1$

tert-Amide : sec-Amide $:$ prim-Amide $=1.83: 1.18: 2.47$ or $1.56: 1: 2.09$ 
Supporting Information

David Edinger

15N-PA3-2 \% DBU in DMSO-d6
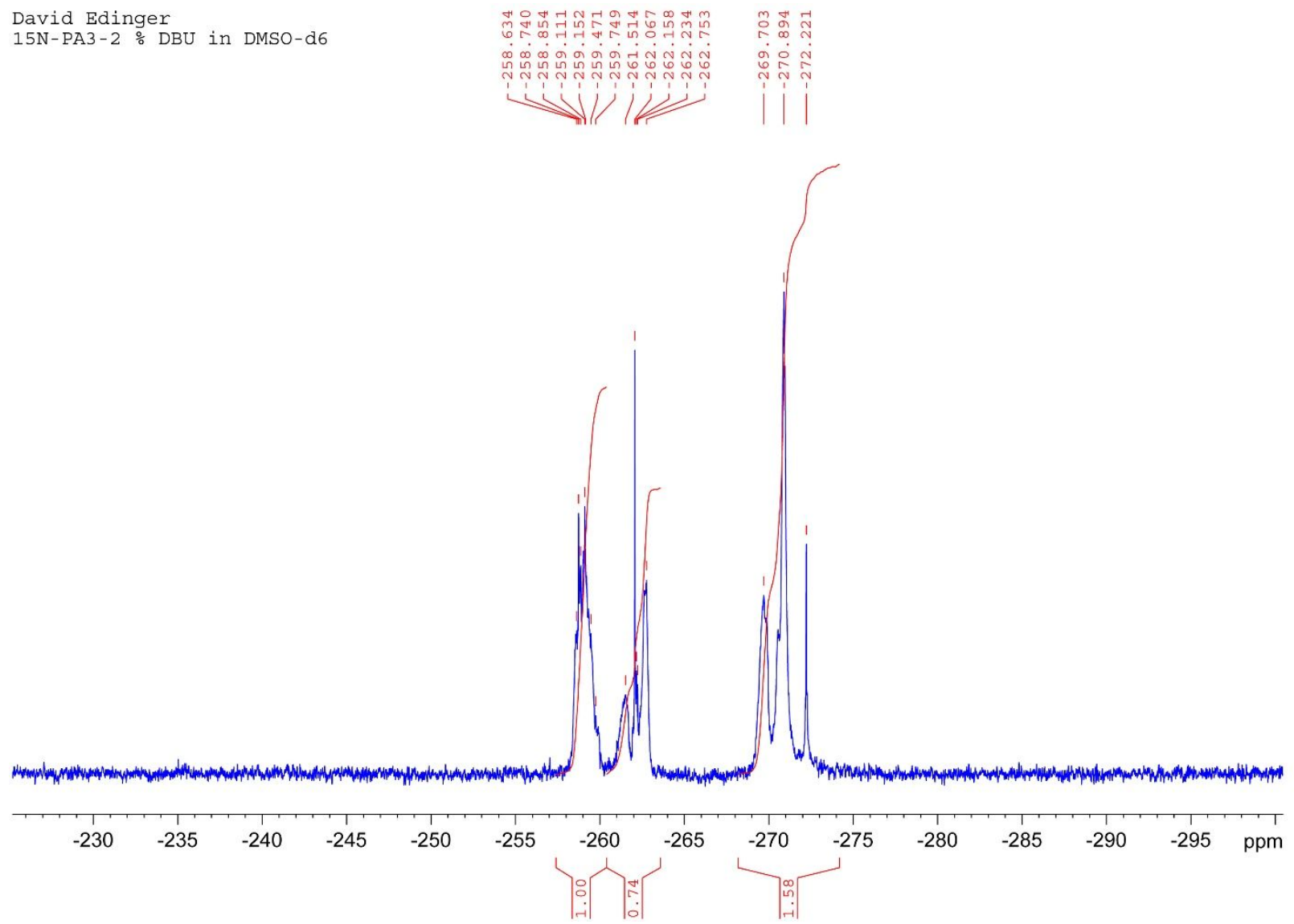

Figure S17. ${ }^{15} \mathrm{~N}\left\{{ }^{1} \mathrm{H}\right\}-\mathrm{NMR}\left(50.70 \mathrm{MHz}, \mathrm{DMSO}-\mathrm{d}_{6}, 25^{\circ} \mathrm{C}\right)$ of the reaction of acrylamide- ${ }^{15} \mathrm{~N}$ with DBU $(2 \mathrm{~mol} \%)$ at $83{ }^{\circ} \mathrm{C}$ after $24 \mathrm{~h}$. Chemical shifts relative to $\mathrm{CH}_{3}{ }^{15} \mathrm{NO}_{2}$.

From integration:

tert-Amide : sec-Amide $:$ prim-Amide $=1.35: 1: 2.14$

Branching $=57.5 \%$

Compared to evaluation of the proton NMR:

tert-Amide $:$ sec-Amide $:$ prim-Amide $=1.56: 1: 2.09$

Branching: $61 \%-\mathrm{NH}: \mathrm{NH}_{2}=1: 2.1$ 
Supporting Information

The average degree of branching (DB) for hyperbranched polymers was defined by Fréchet ${ }^{1}$ as

$\mathrm{DB}=(\mathrm{D}+\mathrm{T}) /(\mathrm{D}+\mathrm{L}+\mathrm{T})$, where $\mathrm{D}$ are dendritic, $\mathrm{L}$ linear and $\mathrm{T}$ terminal groups.

and by Frey² for lower MW as

$\mathrm{DB}=(2 \mathrm{D}) /(2 \mathrm{D}+\mathrm{L})$

Accordingly, with values obtained above

$$
\begin{aligned}
& \mathbf{D B}_{\text {Fréchet }}=(1.35+2.14) /(1.25+1+2.14)=\mathbf{0 . 7 7 8} \\
& \text { and } \\
& \mathbf{D B}_{\text {Frey }}=(2 \cdot 1.35) /(2 \cdot 1.25+1)=\mathbf{0 . 7 1 4}
\end{aligned}
$$

${ }^{1}$ Hawker, C. J.; Lee, R.; Fréchet, J. M. J. One step synthesis of hyperbranched dendritic polyesters. J. Am. Chem. Soc. 1991, 113, 4583-4588. DOI: 10.1021/ja00012a030

${ }^{2}$ Hölter, D.; Burgath, A.; Frey, H. Degree of branching in hyperbranched polymers. Acta. Polym. 1997, 48, 30-35. DOI: 10.1002/actp.1997.010480105 
Supporting Information

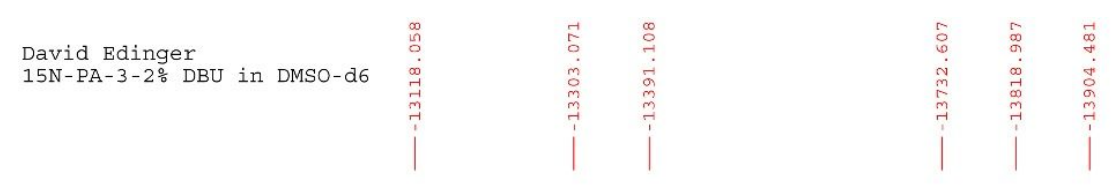

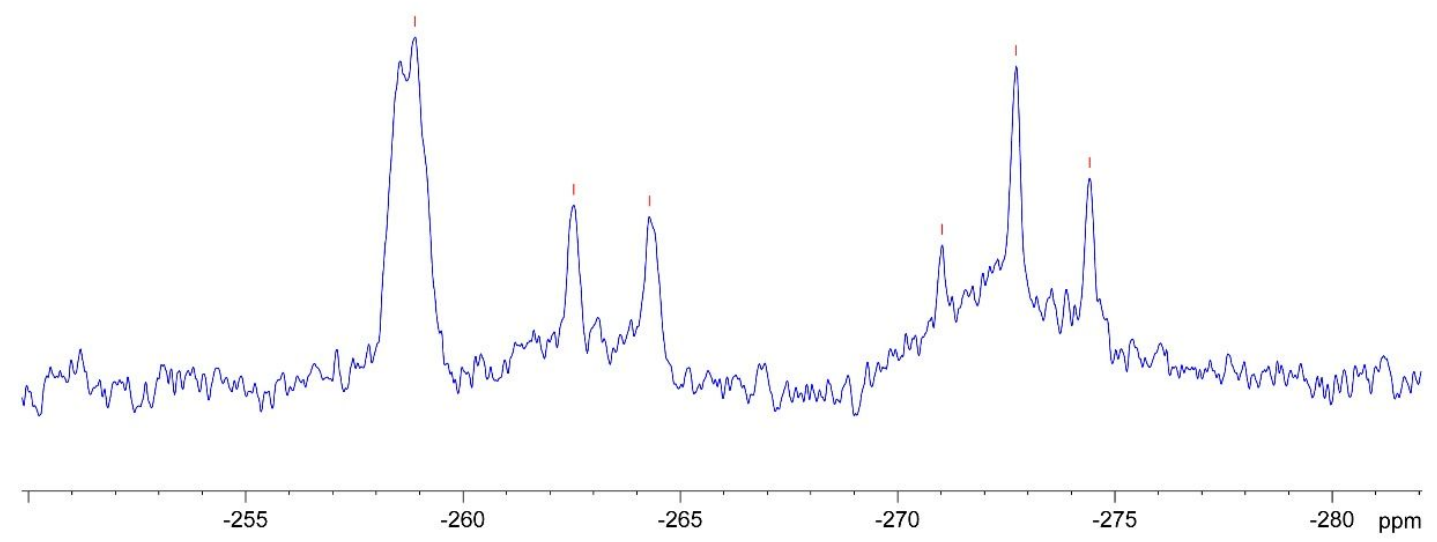

David Edinger

$15 \mathrm{~N}-\mathrm{PA}-3-2 \% \mathrm{DBU}$ in DMSO-d6
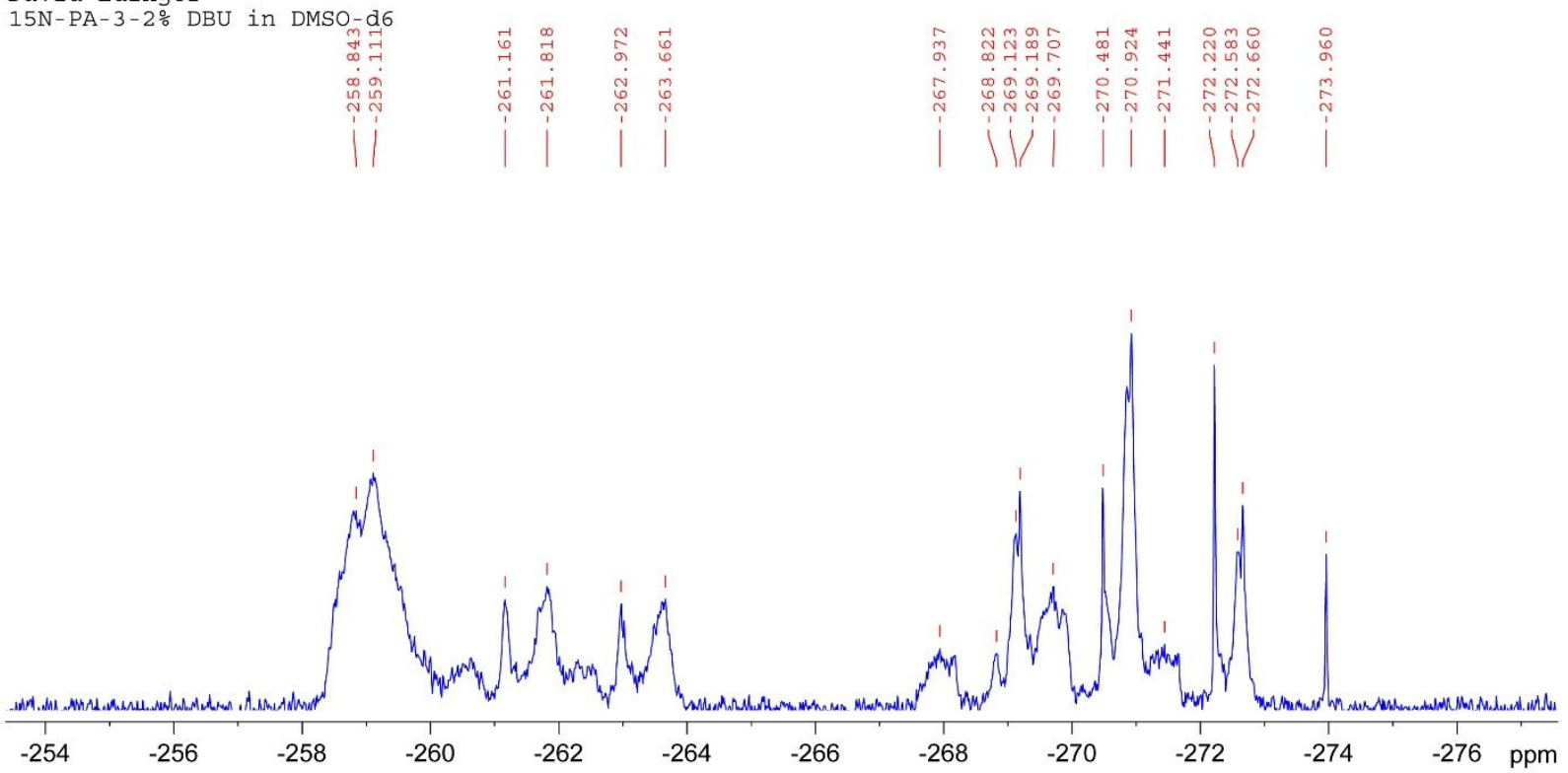

Figure S18. above: ${ }^{15} \mathrm{~N}-\mathrm{NMR}\left(50.70 \mathrm{MHz}, \mathrm{DMSO}-\mathrm{d}_{6}, 90^{\circ} \mathrm{C}\right)$ of the reaction of acrylamide $-{ }^{15} \mathrm{~N}$ with DBU (2 mol\%) after $24 \mathrm{~h}$. below: ${ }^{15} \mathrm{~N}-\mathrm{NMR}\left(50.70 \mathrm{MHz}, \mathrm{DMSO}-\mathrm{d}_{6}, 30^{\circ} \mathrm{C}\right)$ of the reaction of acrylamide- ${ }^{15} \mathrm{~N}$ with DBU $(2 \mathrm{~mol} \%)$ after $24 \mathrm{~h}$. Chemical shifts relative to $\mathrm{CH}_{3}{ }^{15} \mathrm{NO}_{2}$. 


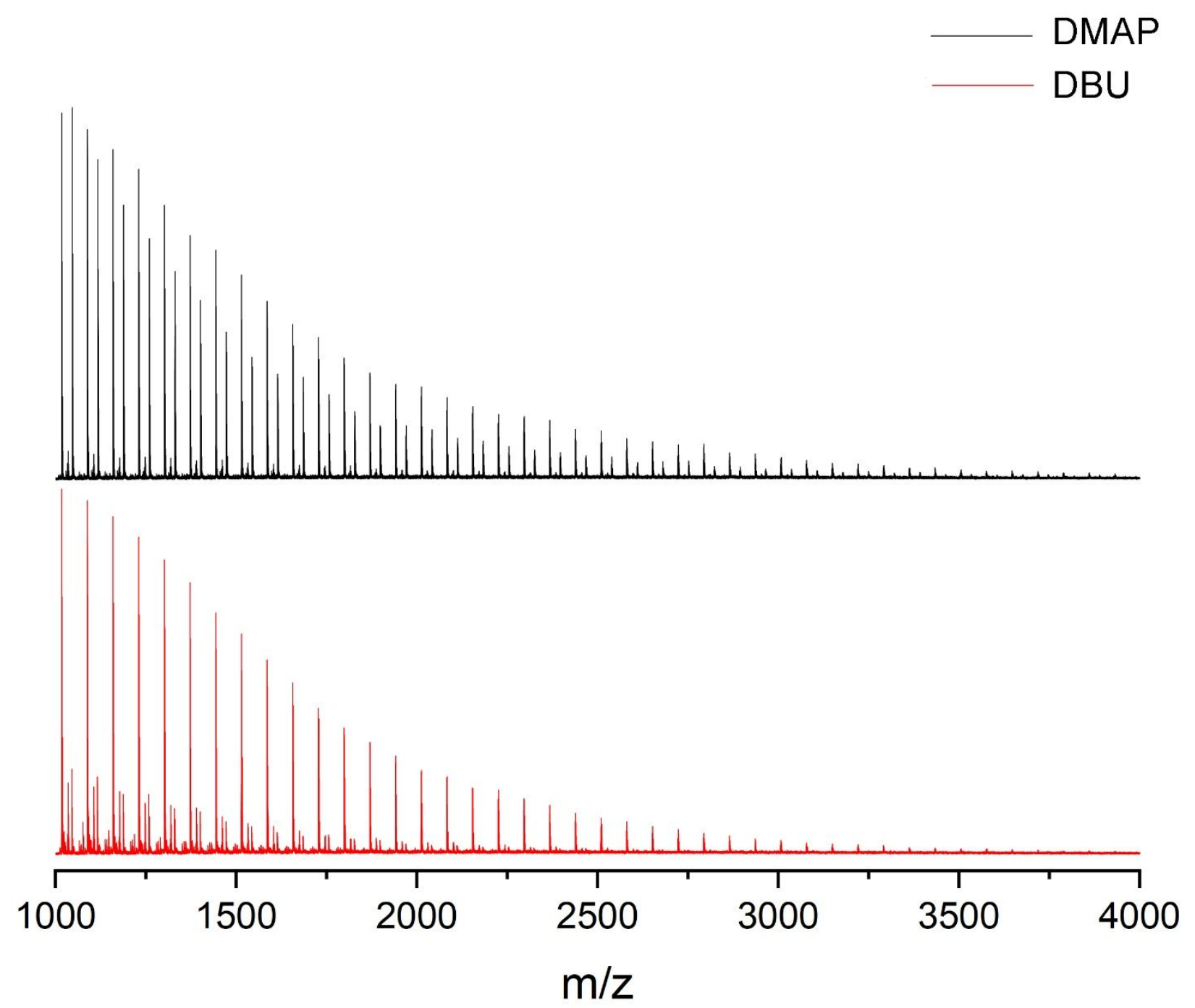

Figure S19. above: MALDI-TOF MS of the reaction of acrylamide with DMAP (2 mol\%) at 83 ${ }^{\circ} \mathrm{C}$ after $24 \mathrm{~h}$ (Table 1, Entry 3$)$. below: the reaction of acrylamide with DBU $(2 \mathrm{~mol} \%)$ at $83{ }^{\circ} \mathrm{C}$ after $24 \mathrm{~h}$ (Table 1, Entry 4). 
Table S1. Overview on characterization data of PA 3 prepared with 2, 1, 0.5 and $0.1 \mathrm{~mol} \% \mathrm{DBU}^{\mathrm{a}}$

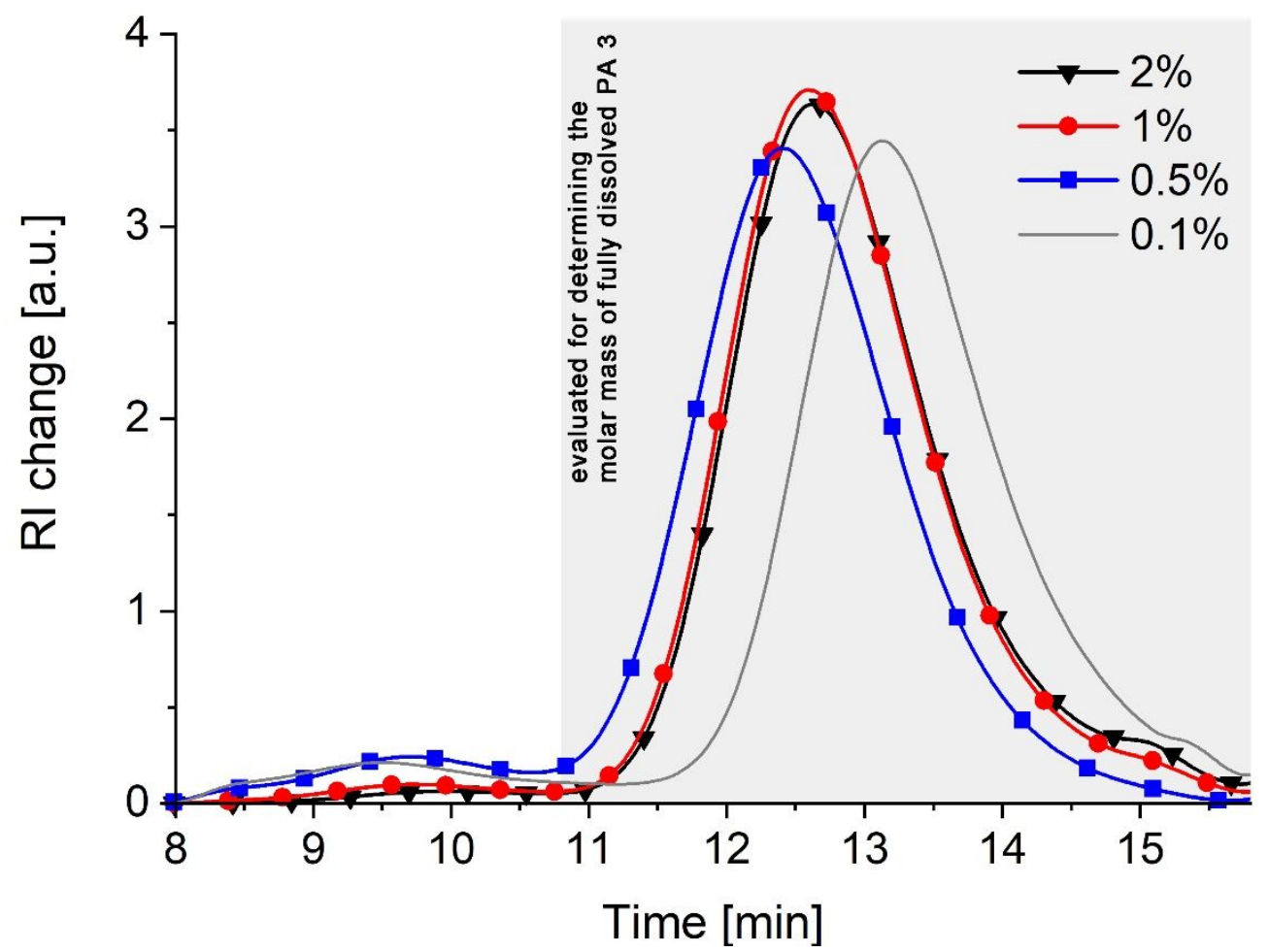

\begin{tabular}{cccccc}
$\begin{array}{c}\text { DBU } \\
{[\mathbf{m o l} \text { \%] }}\end{array}$ & $\begin{array}{c}\text { Conversion } \\
{[\mathbf{\%}]^{\mathbf{b}}}\end{array}$ & $\begin{array}{c}\text { Branching } \\
\text { ratio n/m }[\mathbf{\%}]^{\mathbf{c}}\end{array}$ & $\begin{array}{c}\mathbf{M}_{\mathbf{n}} \\
{[\mathbf{k g} / \mathbf{m o l}]^{\mathbf{d}}}\end{array}$ & $\begin{array}{c}\mathbf{M}_{\mathbf{w}} \\
{[\mathbf{k g} / \mathbf{m o l}]}\end{array}$ & Ð \\
\hline 2 & $>99$ & $51 \pm 2$ & $6.9 \pm 0.1$ & $15.0 \pm 0.1$ & 2.2 \\
1 & $>99$ & $50 \pm 2$ & $10.8 \pm 0.1$ & $19.4 \pm 0.1$ & 1.8 \\
0.5 & $>99$ & $52 \pm 2$ & $23.4 \pm 0.2$ & $40.5 \pm 0.1$ & 1.7 \\
$0.1^{\mathrm{e}}$ & $97 \pm 1$ & $55 \pm 2$ & $9.5 \pm 0.1$ & $15.7 \pm 0.1$ & 1.7
\end{tabular}

${ }^{a}$ reaction conditions: $1 \mathrm{~g}$ of 1 , solvent free, $83{ }^{\circ} \mathrm{C}$ oil bath temperature, $24 \mathrm{~h} .{ }^{\mathrm{b}}$ double bond conversion calculated using the integration of the respective ${ }^{1} \mathrm{H}-\mathrm{NMR}$ spectrum in $\mathrm{D}_{2} \mathrm{O}$ at $25^{\circ} \mathrm{C}$ according to (integral $\left.{ }_{3.95-3.22} / 2\right) /\left(\left(\right.\right.$ integral $\left._{3.95-3.22} / 2\right)+\left(\right.$ integral $\left.\left._{5.89-5.63}\right)\right) \cdot 100{ }^{c}{ }^{c}$ branching ratio (branched repeat units / linear repeat units) calculated using the integration of the respective ${ }^{1} \mathrm{H}$ NMR spectrum in $\mathrm{D}_{2} \mathrm{O}$ at $25^{\circ} \mathrm{C}$ according to (integral $\left.{ }_{3.95-3.44} / 2\right) /\left(\right.$ integral $\left._{3.95-3.44} / 2\right)+\left(\right.$ integral $_{3.44-}$ 3.22)) $100 .{ }^{d}$ SEC-MALS in $0.1 \mathrm{M} \mathrm{LiBr}$ in DMSO at $50^{\circ} \mathrm{C}$, the peak at longer retention time was evaluated; the small peaks which elute between 8 and 11 min corresponds to $M_{w}$-values between 1000 and $4000 \mathrm{~kg} / \mathrm{mol}$. ${ }^{\mathrm{e}}$ prepared at $90{ }^{\circ} \mathrm{C}$ oil bath temperature. 


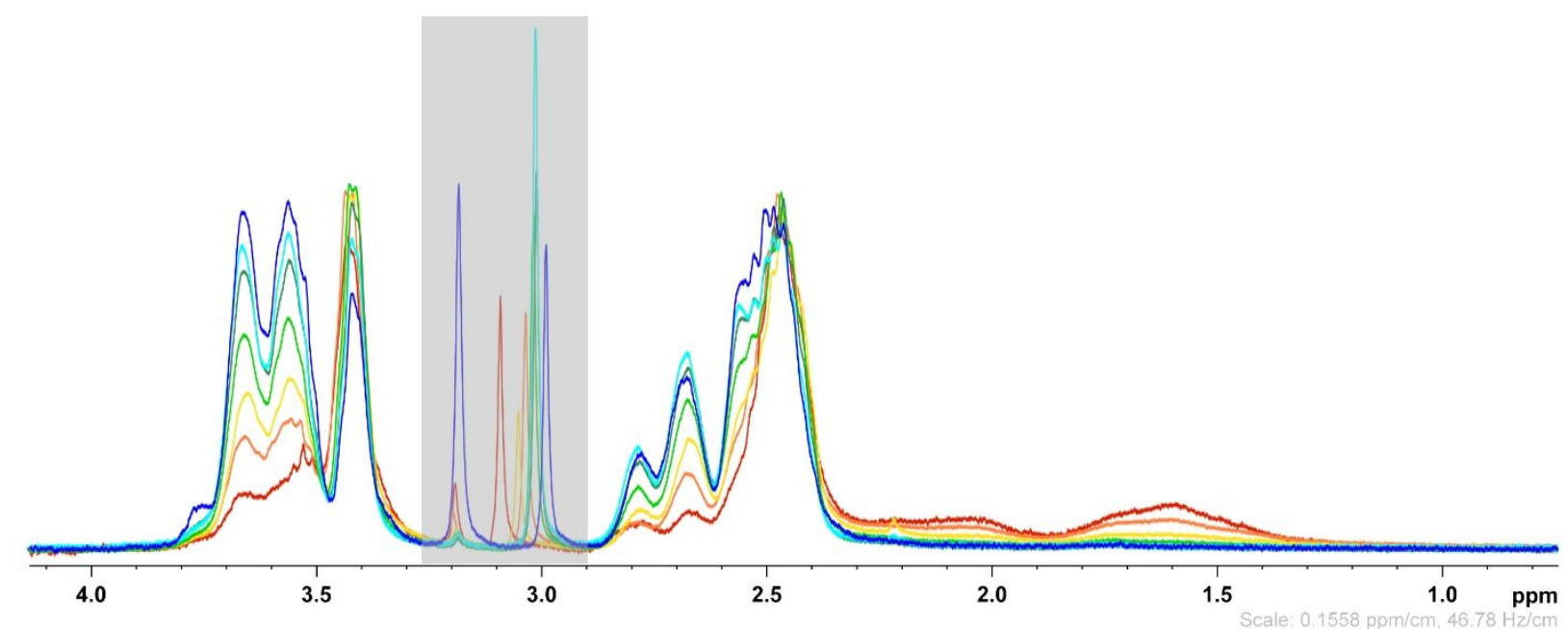

Figure S20. Part of the ${ }^{1} \mathrm{H}-\mathrm{NMR}\left(300 \mathrm{MHz}, \mathrm{D}_{2} \mathrm{O}, 25^{\circ} \mathrm{C}\right)$ of polymerizations of acrylamide conducted with $2 \mathrm{~mol} \%$ DMAP at $83{ }^{\circ} \mathrm{C}$ (blue), $100{ }^{\circ} \mathrm{C}$ (turquoise), $120{ }^{\circ} \mathrm{C}$ (dark green), $140{ }^{\circ} \mathrm{C}$ (green), $160{ }^{\circ} \mathrm{C}$ (yellow), $180^{\circ} \mathrm{C}$ (orange) and $200{ }^{\circ} \mathrm{C}$ (red). In the grey box signals for DMAP (at 3.0 ppm free DMAP, about 3.3 ppm alkylated DMAP): Broad signals below 2.3 ppm are indicative for vinyl type repeat units.

Table S2. Reaction conditions and double bond conversion for the polymerization of acrylamide in the Monowave 50 reactor (from Anton Paar $\mathrm{GmbH}$ ).

\begin{tabular}{ccc}
\hline $\mathrm{T}\left[{ }^{\circ} \mathrm{C}\right]$ & $\mathrm{t}[\mathrm{h}]$ & $\begin{array}{c}\text { Double bond } \\
\text { conversion }[\%]\end{array}$ \\
\hline 83 & 24 & 91 \\
100 & 12 & 95.5 \\
120 & 6 & 96 \\
140 & 3 & 97 \\
160 & 2 & 97 \\
180 & 1 & 96 \\
200 & 0.5 & 97 \\
\hline
\end{tabular}


Supporting Information

PROPAGATION

via acryl-terminated species

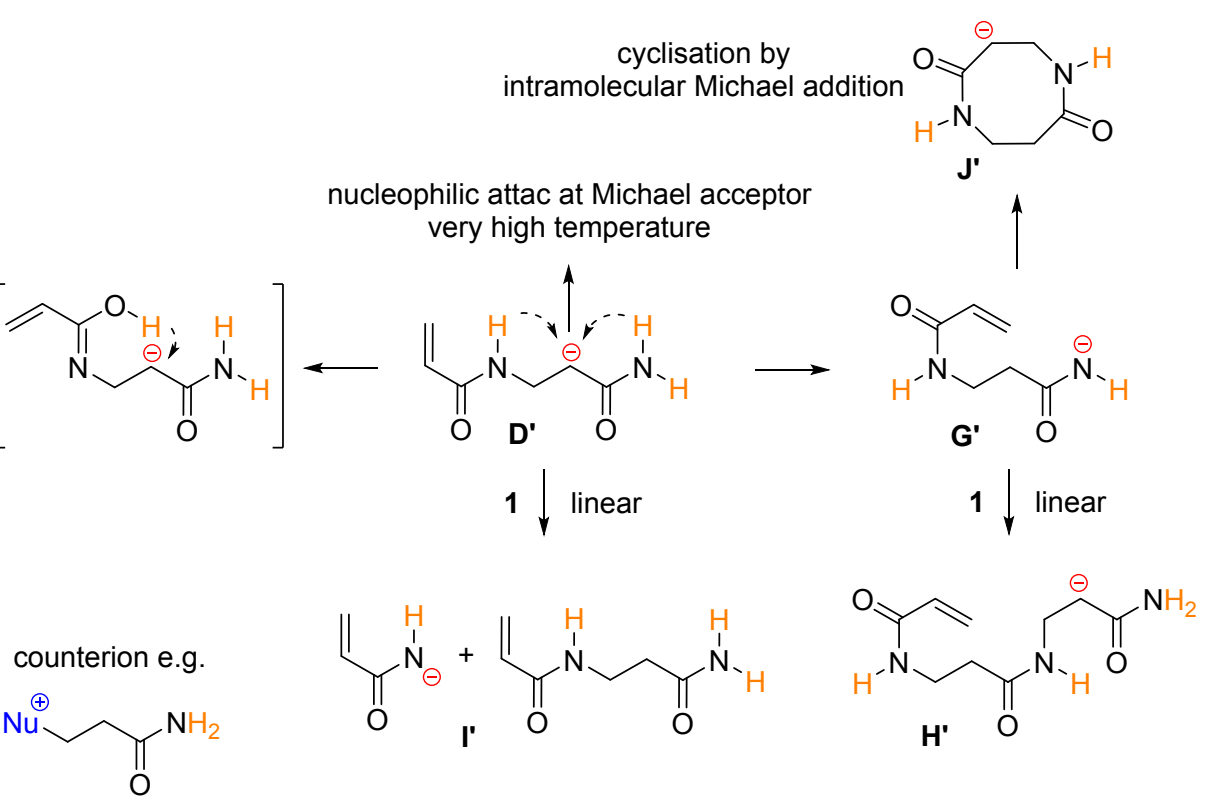

Figure S21. Alternative mechanism for the propagation not involving zwitter-ions. 
Supporting Information
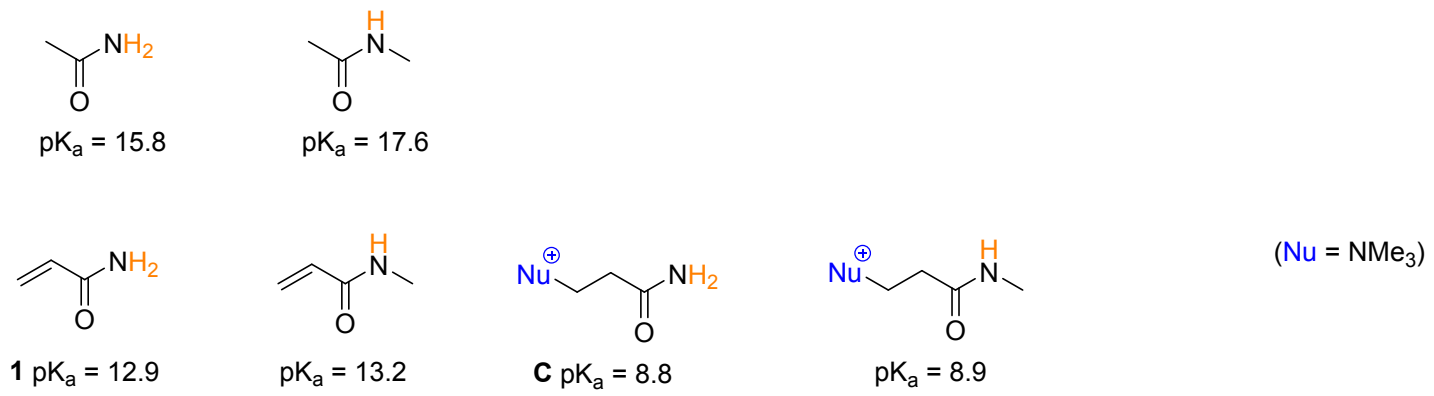<smiles></smiles><smiles>CN(CCC(N)=O)C(=O)CC[N+]#[Rh]</smiles><smiles>CN(C)C(=O)CCNC(=O)CCON</smiles><smiles>C=CC(=O)NCCC(N)=O</smiles><smiles>C=CC(=O)N(C)CCC(N)=O</smiles><smiles>C=CC(=O)NCCC(=O)N(C)C</smiles><smiles>CC(=O)NCCC(N)=O</smiles><smiles>CC(=O)N(C)CCC(N)=O</smiles><smiles>CC(=O)NCCC(=O)N(C)C</smiles>

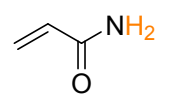

$1 \mathrm{pK}_{\mathrm{a}}=12.9$<smiles>C=CC(=O)NCCC(N)=O</smiles>

I': $\mathrm{pK}_{\mathrm{a}}=12.8$<smiles>C=CC(=O)NCCC(=O)NCCC(N)=O</smiles>

$\mathrm{pK}_{\mathrm{a}}=10.2$

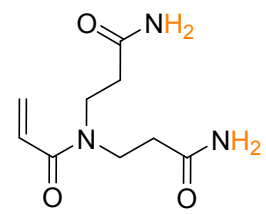

$\mathrm{pK}_{\mathrm{a}}=10.6$<smiles>C=CC(=O)NCCC(=O)N(CCC(N)=O)CCC(N)=O</smiles>

$\mathrm{pK}_{\mathrm{a}}=9.3$<smiles>C=CC(=O)N(CCC(N)=O)CCC(=O)NCCC(N)=O</smiles>

$\mathrm{pK}_{\mathrm{a}}=7.8$

Figure S22. $\mathrm{pK}_{\mathrm{a}}$ in water; data according neural network with $\mathrm{RMSE}=1.60$ and and $\mathrm{r} 2=0.930$ (80:20 train test split) retrieved from the $\mathrm{pK}_{\mathrm{a}}$ prediction platform-home page: pka.luo-group.com. 
Supporting Information
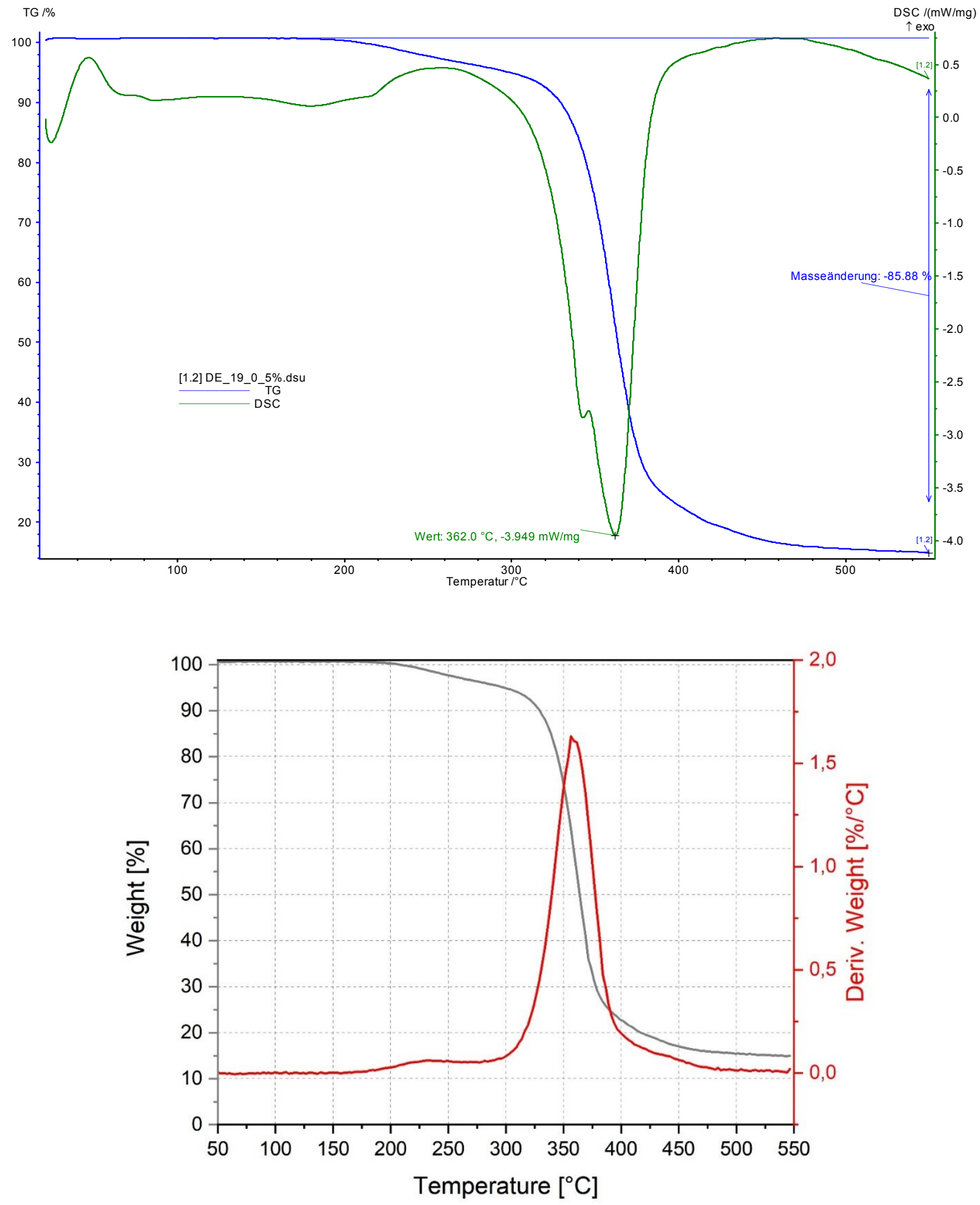

Figure S23. Thermogravimetry of polyacrylamide prepared with $0.5 \mathrm{~mol} \%$ of DBU. 
Supporting Information
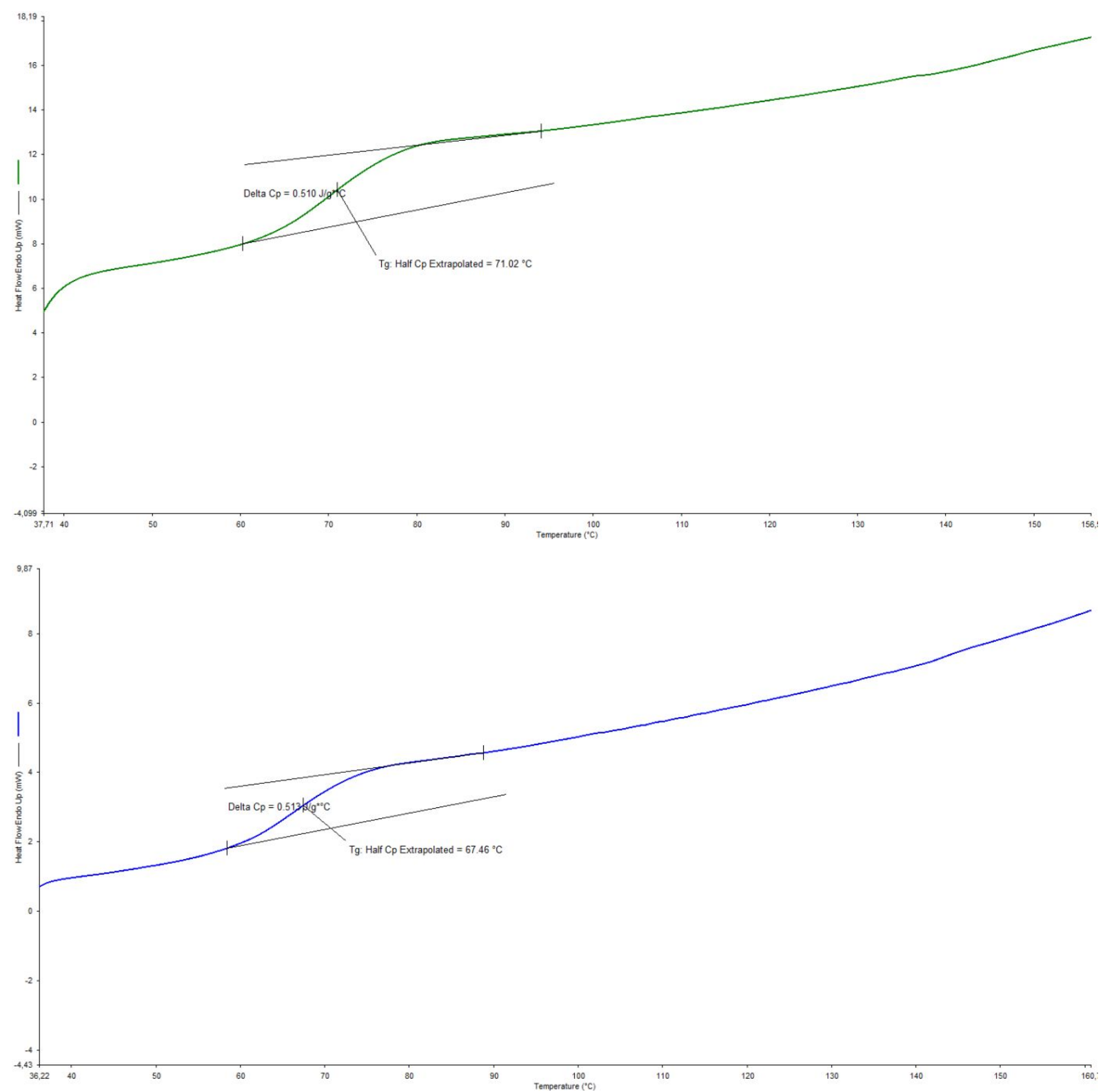

Figure S24. DSC of polyacrylamide prepared with $0.5 \mathrm{~mol} \%$ of DBU. Above: $2^{\text {nd }}$ heating run recorded with $40^{\circ} / \mathrm{min}$; below: $3^{\text {nd }}$ heating run recorded with $20^{\circ} / \mathrm{min}$. 
Supporting Information

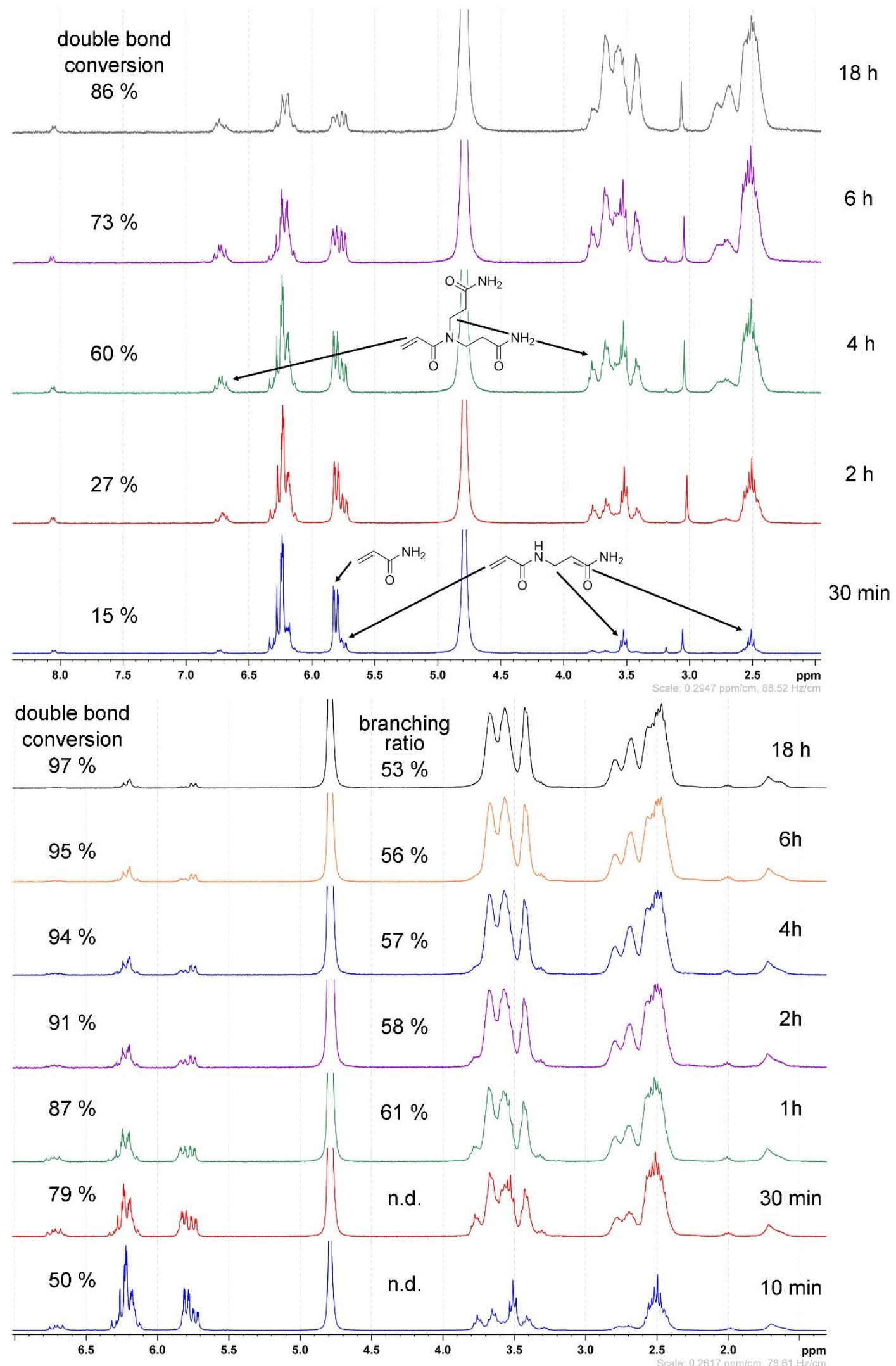

Figure S25. ${ }^{1} \mathrm{H}-\mathrm{NMR}$ of the polymerization of acrylamide with DMAP ( $2 \mathrm{~mol} \%$, above) and DBU ( $2 \mathrm{~mol} \%$, below) conducted at $83{ }^{\circ} \mathrm{C}$ monitored over time. 